\title{
Role of Oxidative and Nitro-Oxidative Damage in Silver Nanoparticles Cytotoxic Effect against Human Pancreatic Ductal Adenocarcinoma Cells
}

\author{
Ewelina Barcińska, ${ }^{1}$ Justyna Wierzbicka, ${ }^{2}$ Agata Zauszkiewicz-Pawlak, ${ }^{2}$ Dagmara Jacewicz, ${ }^{3}$ \\ Aleksandra Dabrowska, ${ }^{3}$ and Iwona Inkielewicz-Stepniak (i) ${ }^{1}$ \\ ${ }^{1}$ Department of Medical Chemistry, Medical University of Gdansk, Debinki 1, 80-211 Gdansk, Poland \\ ${ }^{2}$ Department of Histology, Medical University of Gdansk, Debinki 1, 80-211 Gdansk, Poland \\ ${ }^{3}$ Faculty of Chemistry, University of Gdańsk, Wita Stwosza 63, 80-308 Gdańsk, Poland \\ Correspondence should be addressed to Iwona Inkielewicz-Stepniak; iinkiel@gumed.edu.pl
}

Received 21 April 2018; Revised 26 June 2018; Accepted 5 July 2018; Published 16 August 2018

Academic Editor: Jeferson L. Franco

Copyright () 2018 Ewelina Barcińska et al. This is an open access article distributed under the Creative Commons Attribution License, which permits unrestricted use, distribution, and reproduction in any medium, provided the original work is properly cited.

\begin{abstract}
Pancreatic ductal adenocarcinoma is one of the most aggressive human malignancies, where the 5-year survival rate is less than $4 \%$ worldwide. Successful treatment of pancreatic cancer is a challenge for today's oncology. Several studies showed that increased levels of oxidative stress may cause cancer cells damage and death. Therefore, we hypothesized that oxidative as well as nitrooxidative stress is one of the mechanisms inducing pancreatic cancer programmed cell death. We decided to use silver nanoparticles (AgNPs) (2.6 and $18 \mathrm{~nm}$ ) as a key factor triggering the reactive oxygen species (ROS) and reactive nitrogen species (RNS) in pancreatic ductal adenocarcinoma cells (PANC-1). Previously, we have found that AgNPs induced PANC-1 cells death. Furthermore, it is known that AgNPs may induce an accumulation of ROS and alteration of antioxidant systems in different type of tumors, and they are indicated as promising agents for cancer therapy. Then, the aim of our study was to evaluate the implication of oxidative and nitro-oxidative stress in this cytotoxic effect of AgNPs against PANC-1 cells. We determined AgNP-induced increase of ROS level in PANC-1 cells and pancreatic noncancer cell (hTERT-HPNE) for comparison purposes. We found that the increase was lower in noncancer cells. Reduction of mitochondrial membrane potential and changes in the cell cycle were also observed. Additionally, we determined the increase in RNS level: nitric oxide (NO) and nitric dioxide $\left(\mathrm{NO}_{2}\right)$ in PANC-1 cells, together with increase in family of nitric oxide synthases (iNOS, eNOS, and nNOS) at protein and mRNA level. Disturbance of antioxidant enzymes: superoxide dismutase (SOD1, SOD2, and SOD3), glutathione peroxidase (GPX-4) and catalase (CAT) were proved at protein and mRNA level. Moreover, we showed cells ultrastructural changes, characteristic for oxidative damage. Summarizing, oxidative and nitro-oxidative stress and mitochondrial disruption are implicated in AgNPs-mediated death in human pancreatic ductal adenocarcinoma cells.
\end{abstract}

\section{Introduction}

Pancreatic cancer is a very debilitating and refractory cancer. Although it accounts for only $3 \%$ of all cancers worldwide, it is the fourth leading cause of cancer death [1]. The most common type of pancreatic cancer is adenocarcinoma, a type of exocrine pancreatic cancer which is classified as pancreatic ductal adenocarcinoma [2-4]. Due to the fact that the ethology of pancreatic cancer has not been unequivocally described and an effective pancreatic cancer therapy has not been developed, successful diagnosis and treatment of pancreatic cancer are one of the greatest problems of lastday oncology $[2,3]$. In recent years, numerous studies have claimed that AgNPs, due to their unique cytotoxic features, size- and shape-depending, antiproliferative, and apoptosisinducing activity, can be successfully used as antitumor agents [3-5]. Indeed, AgNP-induced cancer cell death by apoptosis, necroptosis, autophagy, and necrosis have been 
observed [6, 7]. However, the molecular mechanism involved in the cytotoxicity of AgNPs against cancer cells is still underway to clarify [8]. Some studies indicate that nanocytotoxic effect is caused by induction of oxidative and/or nitrooxidative stress $[9,10]$. Overgeneration of ROS and RNS in cells can result in pathological processes through damage to various cellular components, DNA breaks, and impairment of antioxidant potential and cancerogenesis [11]. Accordingly, we hypothesized that generation of oxidative and nitro-oxidative stress using AgNPs could be a new anticancer strategy in the future. During the last decades, it has become clear that ROS and RNS may also play an important role in cell cycle regulation and takes part in stress-induced programmed cells death [12]. Modulation of ROS and RNS metabolism and recruitment of cells to the sensitive phase of the cell cycle can have a positive therapeutic impact in anticancer strategy [13]. ROS are essential secondary messengers in multiple signalling pathways leading to cell death including necrosis, autophagy, mitotic catastrophe, and apoptosis $[14,15]$. Oxidative stress-induced programed cells death could be associated with mitochondrial membrane depolarization and mitochondrial remodelling through fission, fusion, or mitophagy $[16,17]$. On the other hand, it has been documented that ROS play a crucial role in the transformation of nonmalignant to malignant cells and survival of cancer cells [18-20]. Furthermore, the effects of AgNP-associated metabolic disorders and damage to the antioxidant system has already been demonstrated in cancer cells $[21,22]$. Reduction of level as well as activity of superoxide dismutase in cells emerges rapidly as a novel target for cancer therapy [23]. Importantly, it has been noticed that the SOD1 gene is overexpressed in cancers cells [24]. Considering the above-mentioned findings, the aim of our study was to evaluate the cytotoxic effect of AgNP in relation to oxidative and nitro-oxidative stress generation, antioxidant system impairment, mitochondrial damage, and cell cycle disturbance in human pancreatic ductal adenocarcinoma cells.

\section{Materials and Methods}

2.1. Chemicals. AgNPs $(2.6 \mathrm{~nm}$ and $18 \mathrm{~nm}$ suspended in water) were purchased from the US Research Nanomaterials, USA.

2.2. Characterization of AgNPs. The characteristics of the AgNPs have been presented in our previous study $[6,25$, 26]. We showed stability and monodispersity of 2.6 and $18 \mathrm{~nm}$ AgNPs in SF culture. We confirmed the negative charge, regular, spherical shape and the presence of silver elements $(\mathrm{Ag})$ in water suspension by TEM with EDS. We described sizes ranging from $1-5 \mathrm{~nm}$ with a mean diameter of $2.6 \pm 0.8 \mathrm{~nm}$ for smaller AgNPs and a size range of $10-26 \mathrm{~nm}$ with a mean diameter of $18 \pm 2.6 \mathrm{~nm}$ for the bigger ones. The released $\mathrm{Ag}^{+}$from $2.6 \mathrm{AgNPs}$ and $18 \mathrm{~nm}$ AgNPs was $2.8 \mu \mathrm{g} / \mathrm{mL}$ and $0.66 \mu \mathrm{g} / \mathrm{mL}$, respectively.

2.3. Cells Culture. Human pancreatic ductal carcinoma PANC-1 (CRL-1469) and immortalized human pancreas duct epithelial cell line hTERT-HPNE (CRL-4023) were obtained from the American Type Culture Collection (ATCC). Cells were maintained as a monolayer culture in $\mathrm{T}-75 \mathrm{~cm}^{2}$ tissue culture flasks. PANC-1 cells were cultured in Dulbecco's modified Eagle's medium with high concentration of glucose (ATCC, cat. number: 30-2002), supplemented with $100 \mu \mathrm{g} / \mathrm{mL}$ fetal bovine serum (FBS), $100 \mu \mathrm{g} / \mathrm{mL}$ of penicillin, and $100 \mu \mathrm{g} / \mathrm{mL}$ of streptomycin, and hTERT-HPNE cells were cultured in a mixture of Dulbecco's modified Eagle's medium without glucose (Sigma-Aldrich, cat. number: D-5030) and Medium M3 Base (Incell Corp., cat. number: M300F-500) (3:1 ratio) with $2 \mathrm{mM}$ L-glutamine adjusted to $1.5 \mathrm{~g} / \mathrm{L}$ sodium bicarbonate and supplemented with $5 \% \mathrm{FBS}, 10 \mathrm{ng} / \mathrm{mL}$ human recombinant EGF, $5.5 \mathrm{mM}$ D-glucose $(1 \mathrm{~g} / \mathrm{L})$, and $750 \mathrm{ng} / \mathrm{mL}$ puromycin. Cell lines were cultured in standard condition: at $37^{\circ} \mathrm{C}$ in a humidified atmosphere of $95 \% \mathrm{O}_{2}, 5 \% \mathrm{CO}_{2}$.

2.4. Treatments. AgNPs concentrations and exposure time used in these experiments were carefully selected according to our previous study showing the half maximal inhibitory concentration $\left(\mathrm{IC}_{50}\right)$ for PANC-1 cells $[6,25,26]$. To prevent aggregation, AgNPs solutions were shaken for 1 minute before usage (according to the manufacturer's protocol). AgNPs were suspended ex tempore in serum free (SF) cell culture medium without FBS and then diluted to the appropriate concentrations.

2.5. Determination of ROS Level. Generation of intracellular ROS level was determined by flow cytometry, detected by $2^{\prime} 7^{\prime}$-dichlorofluorescein $\left(\mathrm{H}_{2} \mathrm{DCF}-\mathrm{DA}\right)$ (Merck, Poland). PANC-1 and hTERT-HPNE cells were seeded into 6-well plates at a density of $2 \times 10^{4}$. The next day, cells were treated with 2.6 or $18 \mathrm{~nm}$ AgNPs in concentrations of $0.5,1.5,2.5,3.5,5$ and $5,10,25,50,100 \mu \mathrm{g} / \mathrm{mL}$ for $24 \mathrm{~h}$ as indicated in Treatments. Afterwards, PANC-1 and hTERT-HPNE cells medium were removed, and $10 \mu \mathrm{M}$ DCF-DA was added to the well for $0.5 \mathrm{~h}$ at $37^{\circ} \mathrm{C}$. Next, the cells were detached with trypsin solution, washed with PBS, and suspended in $1 \mathrm{~mL}$ PBS. Fluorescence of oxidized DCF was measured by flow cytometer at excitation and emission wavelengths of 480 and $525 \mathrm{~nm}$. 10,000 individual cells were measured. The results were expressed as a percent of control.

2.6. Determination of NO Level. NO level in PANC-1 cells was determined by the Muse Cell Analyzer, using Muse ${ }^{\circledR}$ Nitric Oxide Kit (Merck, Poland). The cells were seeded into 6 -well plates at a density of $2 \times 10^{4}$ cells/well. After $24 \mathrm{~h}$ culturing, PANC- 1 cells were treated with 2.6 AgNPs in concentrations of $0.5,1.5$, and $2.5 \mu \mathrm{g} / \mathrm{mL}$ and $18 \mathrm{~nm}$ AgNPs in concertations of 10,25 , and $50 \mu \mathrm{g} / \mathrm{mL}$ for $24 \mathrm{~h}$ as indicated in Treatments. Then, the cells were pelleted and incubated for 30 min with membrane-permeable novel reagent DAXJ2 Orange (Muse Nitric Oxide Reagent, Merck Millipore), according to the manufacturer's protocol. Afterwards, samples cells were analyzed (5000 events/sample) using the Muse Cell Analyzer. The Muse 1.4 analysis software was used to analyze the obtained results. 
TABLE 1: The list of primers used in the study.

\begin{tabular}{lccc}
\hline Gene name & \multicolumn{1}{c}{ Forward primer } & Reverse primer & Annealing temperature \\
\hline RPL37 & TTCTGATGGCGGACTTTACC & CACTTGCTCTTTCTGTGGCA & 60 \\
nNOS & CTCACCCCCTCCTTCGAATACC & AAGCTTGCGATTTGCCTGTCTC & 60 \\
iNOS & ACGGCTCCTTCAAAGAGGCAAA & TAACGCACGTGTCTGCAGATGT & 60 \\
eNOS & ACATGCTGCTGGAAATTGGG & TGGTCCACGATGGTGACTTT & 60 \\
bNOS & AAAGCCCACATGGAAAGGCT & AGGTTCCCTTTGTTGGTGGCAT & 60 \\
CAT & ACGGGGCCCTACTGTAATAA & AGATGCAGCACTGGAAGGAG & 60 \\
SOD1 & CCACACCTTCACTGGTCCAT & CTAGCGAGTTATGGCGACG & 62 \\
SOD2 & TAGGGCTGAGGTTTGTCCAG & CACCGAGGAGAAGTACCAGG & 62 \\
SOD3 & CGAGTCAGAGTTGGGCTCC & TCTCTTGGAGGAGCTGGAAA & 62 \\
\hline
\end{tabular}

2.7. Assessment of $\mathrm{NO}_{2}$ Concentration. Nitrogen dioxide levels in the cytosolic fraction of pancreatic cells (PANC-1 and hTERT-HPNE) were determined on the basis of a standard curve created according to the author's method of Jacewicz [27]. PANC-1 and hTERT-HPNE cells were seeded into 6-well plates at a density of $2 \times 10^{4}$ cells/well for $24 \mathrm{~h}$ and next, treated with 2.6 and $18 \mathrm{~nm}$ AgNPs in concentrations of $0.5,1.5$, and $2.5 \mu \mathrm{g} / \mathrm{mL}$ and 10,25 , and $50 \mu \mathrm{g} / \mathrm{mL}$ for $24 \mathrm{~h}$ as indicated in Treatments. Afterwards, the cells were pelleted and fixed in a $200 \mathrm{mM}$ ice-cold phosphate buffer, pH7.4. The cytosolic fraction was obtained after $20 \mathrm{~min}$ of centrifugation at $100,000 \times \mathrm{g}$ and used for $\mathrm{NO}_{2}$ assessment. Samples were prepared by addition of appropriate amounts of the linsidomine (SIN-1) solution and completion of the appropriate buffer to final $3 \mathrm{~mL}$ volume. A solution of the complex used to determine $\mathrm{NO}_{2}$ concentration was prepared by mixing $0.5 \mathrm{~mL}$ of cis- $\left[\mathrm{Cr}\left(\mathrm{C}_{2} \mathrm{O}_{4}\right)\left(\text { AaraNH}_{2}\right)\left(\mathrm{OH}_{2}\right)_{2}\right]^{+}\left(10^{-3} \mathrm{M}\right)$ with $2 \mathrm{~mL}$ of $0.2 \mathrm{M}$ MES and $2 \mathrm{~mL}$ of $2 \mathrm{M} \mathrm{NaClO}_{4}$. The temperature was maintained at $20^{\circ} \mathrm{C}$ with an accuracy of $\pm 0.1^{\circ} \mathrm{C}$. Nitric dioxide concentrations were computed using Origin 6.0 software on the basis of absorbance variations at $541 \mathrm{~nm}$ using the nonlinear least squares method [28].

2.8. Western Blot Analysis. Protein levels of antioxidant enzymes (SOD1, SOD2, GPX-4, iNOS, eNOS, and nNOS) were detected using Western blotting method. PANC-1 cells were cultured in $10 \mathrm{~cm}$ Petri dishes until it reached about $90 \%$ confluence. Afterwards, cells were treated with 2.6 and $18 \mathrm{~nm}$ AgNPs at concentrations of $0.5,1,1.5,2,2.5$, and $3 \mu \mathrm{g} / \mathrm{mL}$ or $5,10,25$, and $50 \mu \mathrm{g} / \mathrm{mL}$ and incubated $24 \mathrm{~h}$ as indicated in Treatments. Next, culture media was removed; cells were resuspended three times with ice-cold PBS, detached, and centrifuged at $1500 \mathrm{rpm} / \mathrm{min}$ for $5 \mathrm{~min}$ at room temperature. Then, the supernatant was discharged; cells were homogenized with protein lysis buffer $(50 \mathrm{mM}$ Tris pH 7.5, $150 \mathrm{mM} \mathrm{NaCl}, 1 \%$ Triton X-100, 0.1\% SDS) in the presence of protease inhibitor (Roche, cat. number: 04693159001). The protein concentrations were measured by the Bradford method [29]. After electrophoresis, proteins were transferred onto nitrocellulose membrane (Protran ${ }^{\circledR}$, Schleicher and Schuell BioScience) and detected using antibodies: anti-SOD1, anti-SOD2, anti-GPX-4, anti-iNOS, anti-eNOS, and anti-nNOS. $\beta$-Actin was used as a loading control. The immunoactive proteins were determined using an enhanced chemiluminescence (ECL) Western blotting detection kit (Amersham Biosciences, Piscataway, NJ, USA). Protein levels were quantified using densitometry software (ImageQuant Software).

2.9. Real-Time PCR. Changes in genes expression were analyzed by real-time PCR. PANC-1 cells were cultured in $10 \mathrm{~cm}$ Petri dishes about $90 \%$ confluence. Next, cells were incubated for $24 \mathrm{~h}$ with 2.6 and $18 \mathrm{~nm}$ AgNPs at concentrations of $0.5,1.5$, and $2.5 \mu \mathrm{g} / \mathrm{mL}$ or $5.10,25$, and $50 \mu \mathrm{g} / \mathrm{mL}$ as indicated in Treatments. After treatment, total RNA was extracted from cell cultures using the ExtractMe Total RNA Plus Kit (Blirt, Poland) according to the manufacturer's instructions. The concentration and purity of isolated RNA were measured with an Epoch spectrophotometer (BioTek, Winooski, USA). Two micrograms of total RNA were subjected to reverse transcription using a RevertAid ${ }^{\mathrm{TM}}$ First Strand cDNA Synthesis kit (Thermo Fisher Scientific Inc., USA). The primers used for PCR amplification are listed in Table 1. The reactions were performed in duplicate for each primer set with SensiFAST SYBR No-ROX PCR Master Mix (Bioline, UK). $2 \mu \mathrm{L}$ of cDNA diluted 5 -fold and $200 \mathrm{nM}$ of each primer pair. The PCR conditions were $95^{\circ} \mathrm{C}$ for $2 \mathrm{~min}$ followed by 40 cycles of denaturation for $5 \mathrm{sec}$ at $95^{\circ} \mathrm{C}$, annealing for $10 \mathrm{sec}$ at primer-specific temperature, extension for $15 \mathrm{sec}$ at $72^{\circ} \mathrm{C}$, and fluorescence reading for $10 \mathrm{sec}$ at $79^{\circ} \mathrm{C}$. Dynamic melting curve analysis was performed for all reactions. A total reference RNA (Stratagene) was used to generate a standard curve. The data were collected using the StepOnePlus ${ }^{\mathrm{TM}}$ Real-Time PCR System (Life Technologies, USA). The amount of amplified product for each gene was compared to that for the reference gene (RPL37) using a comparative $\Delta \Delta$ CT method and presented as a fold change $\pm \mathrm{SD}$.

2.10. Cell Cycle. Cell cycle analysis was performed using flow cytometry, detected by propidium iodide (PI) (Merck, Poland). PANC-1 cells were seeded at a density of $2 \times 10^{4}$ into 6-well plates. After $24 \mathrm{~h}$ culturing, cells were treated with 2.6 or $18 \mathrm{~nm} \mathrm{AgNPs} \mathrm{in} \mathrm{concentrations} \mathrm{of} \mathrm{0.5,} \mathrm{1.5,}$ and $2.5 \mu \mathrm{g} / \mathrm{mL}$ and 10,25 , and $50 \mu \mathrm{g} / \mathrm{mL}$ for $24 \mathrm{~h}$ as indicated in Treatments. Afterwards, the cells were collected, washed twice with ice-cold PBS, and fixed $24 \mathrm{~h}$ at $4^{\circ} \mathrm{C}$ with $70 \%$ ethanol $/ 30 \%$ PBS solution. The samples were 
ROS

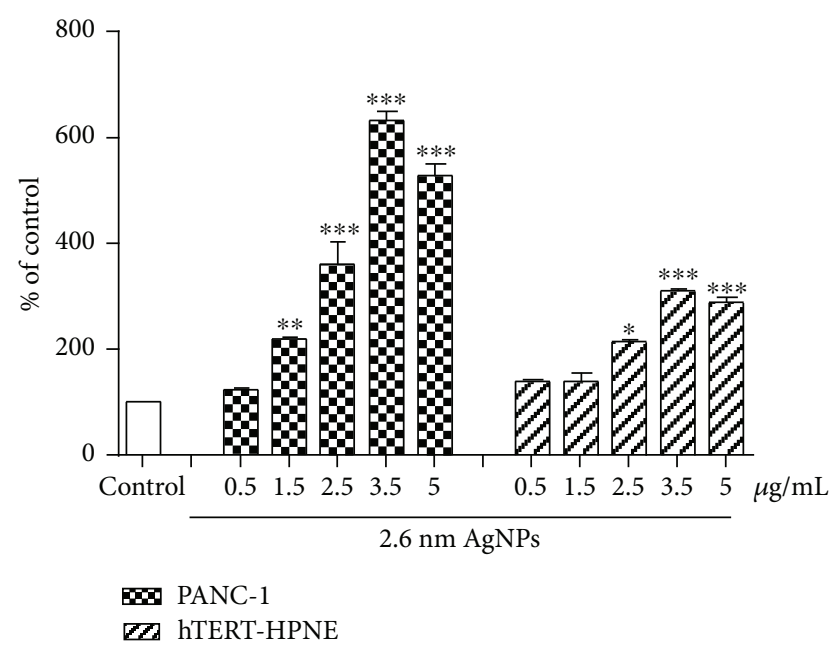

(a)
ROS

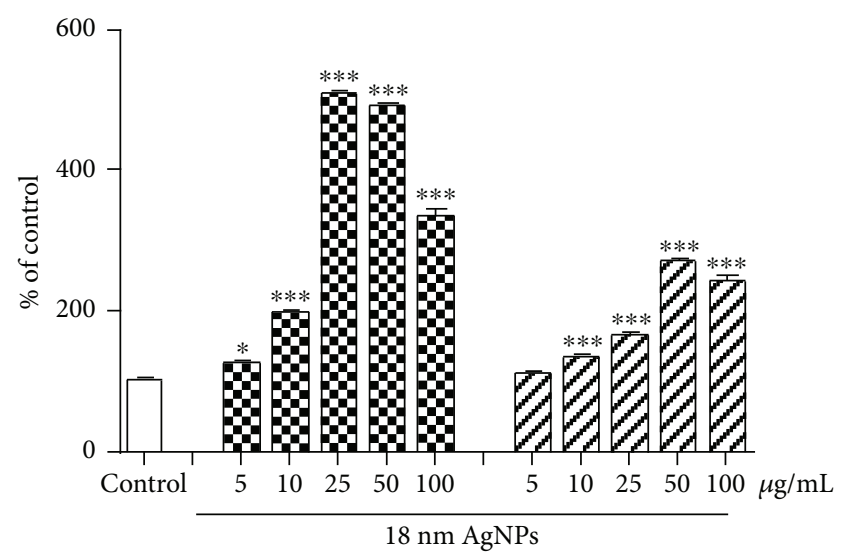

M PANC-1 CA hTERT-HPNE

FIgURE 1: Increase in ROS level in PANC-1 and hTERT-HPNE cells after treatment with $2.6 \mathrm{~nm}$ and $18 \mathrm{~nm}$ AgNPs for $24 \mathrm{~h}$. Data are mean $\pm \mathrm{SD}$ of 3 separate determinations. ${ }^{*} p<0.05 ;{ }^{* *} p<0.01 ;{ }^{* * *} p<0.001$ treatments versus control.

centrifuged, and the ethanol was removed. Subsequently, cells were resuspended in PBS containing RNAse A $(50 \mu \mathrm{g} / \mathrm{mL})$ and PI $(50 \mu \mathrm{g} / \mathrm{ml})$ and incubated for $0.5 \mathrm{~h}$ in room temperature in the dark. PANC-1 cells were analyzed by flow cytometry (BD FACSCalibur ${ }^{\mathrm{TM}}$ ) and CellQuest Pro software. Debris and doublets have been removed by gated appropriate population on FSC/SSC and FL2-A/FL2-W plots before analysis. The percentage of cells in each cell cycle phase was determined by using markers set within the analysis program.

2.11. Changes in Mitochondrial Membrane Potential. Changes in mitochondrial membrane potential were analyzed by Muse Cell Analyzer, using the Muse MitoPotential Assay Kit (Merck, Poland). PANC-1 cells were seeded at a density of $2 \times 10^{4}$ per well in 6 -well plates. After $24 \mathrm{~h}$ of culturing in the standard medium, the cells were treated with $2.6 \mathrm{~nm}$ or $18 \mathrm{~nm}$ as indicated in Treatments in the concentrations range of $0.5-5 \mu \mathrm{g} / \mathrm{mL}$ or $5-100 \mu \mathrm{g} / \mathrm{mL}$ for $24 \mathrm{~h}$. Then, PANC- 1 cells were detached and incubated in $5 \% \mathrm{CO}_{2}$ at $37^{\circ} \mathrm{C}$ with the MitoPotential working solution and Muse MitoPotential 7-AAD reagent according to the manufacturer's protocol (Merck, Poland) [30]. The results were analyzed using Muse 1.4 analysis software.

2.12. Transmission Electron Microscope. Transmission electron microscope (TEM) analysis was performed at $100 \mathrm{kV}$ (JEM 1200EX II, Jeol, Japan). PANC-1 cells were cultured in $10 \mathrm{~cm}$ Petri dishes and treated with $2.6 \mathrm{~nm}$ AgNPs in concentrations of $0.5,2.5$, and $5 \mu \mathrm{g} / \mathrm{mL}$ or $18 \mathrm{~nm}$ AgNPs in concentrations of $5,10,25,50$, and $100 \mu \mathrm{g} / \mathrm{mL}$ as indicated in Treatments. Afterwards, cells were fixed in $2.5 \%$ glutaraldehyde in $0.1 \mathrm{mM}$ sodium-cacodylate buffer and prepared according to the previously described method $[6,25]$.

2.13. Statistical Analysis. The obtained data were expressed as mean \pm SD for triplicate determination of 3-4 separate experiments. The results were analyzed using one-way ANOVA and Tukey's post hoc test, and $p$ value $<0.05$ was considered statistically significant.

\section{Results}

3.1. Increase in ROS Level in PANC-1 Cells after Treatment with AgNPs. We investigated the endogenous ROS level in pancreatic cancer cells after $24 \mathrm{~h}$ exposure to AgNPs compared with nontumor cells of the same tissue, and we found increased ROS level in both cell lines (see Figure 1). However, ROS level was about 2 times lower in hTERT-HPNE cells than in PANC-1 cells after treatment with $2.6 \mathrm{~nm}$ AgNPs at concentrations of $1.5,2.5,3.5$, and $5 \mu \mathrm{g} / \mathrm{mL}$ or $18 \mathrm{~nm}$ AgNPs at concentrations of $10,25,50$, and $100 \mu \mathrm{g} / \mathrm{mL}$. Moreover, incubation of pancreatic cancer cells with $2.6 \mathrm{~nm}$ AgNPs (at a concentration of $3.5 \mu \mathrm{g} / \mathrm{mL}$ ) led to a 6 -fold increase in intracellular ROS level as compared with control cells. $18 \mathrm{~nm}$ AgNPs at concentrations of 25 and $50 \mu \mathrm{g} / \mathrm{mL}$ accelerated ROS production to 4 -fold above control values. On the other hand, we noticed a slight decrease of ROS level in PANC-1 cells treated with highest concentrations $(5 \mu \mathrm{g} / \mathrm{mL}$ and $100 \mu \mathrm{g} / \mathrm{mL}$ ) of 2.6 and $18 \mathrm{~nm}$ AgNPs.

Next, we investigated the role of RNS: $\mathrm{NO}$ and $\mathrm{NO}_{2}$ in AgNP-induced pancreatic cancer cells death.

3.2. Impact on RNS: $\mathrm{NO}$ and $\mathrm{NO}_{2}$ and Nitric Oxide Synthases Protein and mRNA Level in PANC-1 Cells after Treatment with AgNPs. We demonstrated that $24 \mathrm{~h}$ incubation of PANC-1 cells with $0.5-5 \mu \mathrm{g} / \mathrm{mL}$ of $2.6 \mathrm{~nm} \mathrm{AgNPs}$ or 5$100 \mu \mathrm{g} / \mathrm{mL}$ of $18 \mathrm{~nm}$ AgNPs caused an increase of NO level in a concentration-dependent manner (see Figure 2(a)). The level of NO was $58.8 \%$ in cells incubated with minimal concentration $(0.5 \mu \mathrm{g} / \mathrm{mL})$ and about $97 \%$ in cells incubated with highest $(3.5$ and $5 \mu \mathrm{g} / \mathrm{mL})$ concentration of $2.6 \mathrm{~nm}$ AgNPs when untreated cells showed $1 \%$ of NO. In PANC-1 cells treated with 5, 10, 25, 50, and $100 \mu \mathrm{g} / \mathrm{mL}, 18 \mathrm{~nm}$ AgNPs 
NO

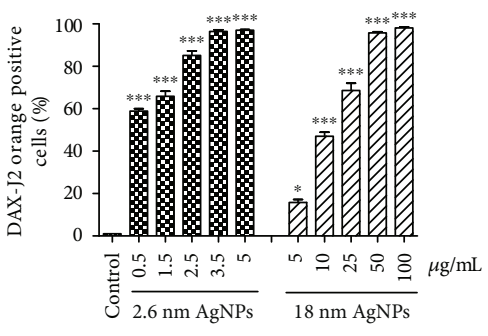

(a)

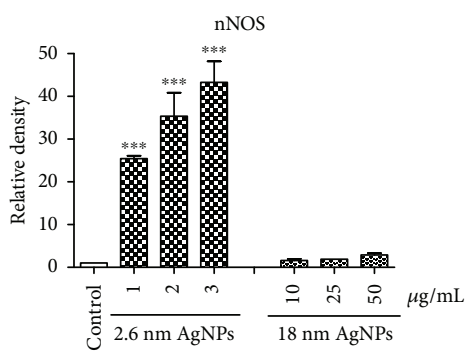

(d)

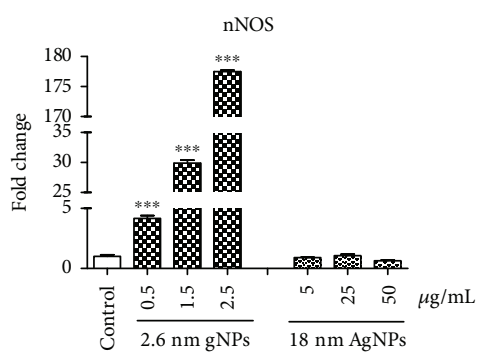

(g)

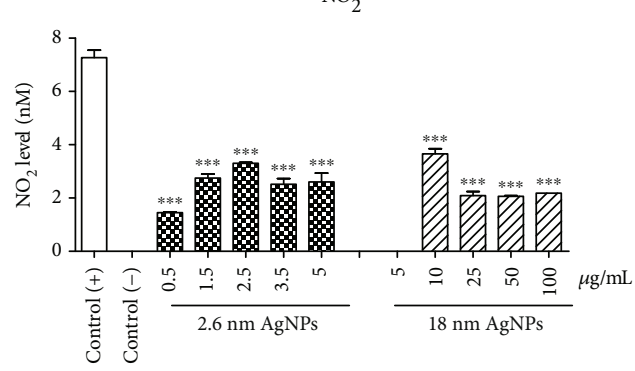

(b)

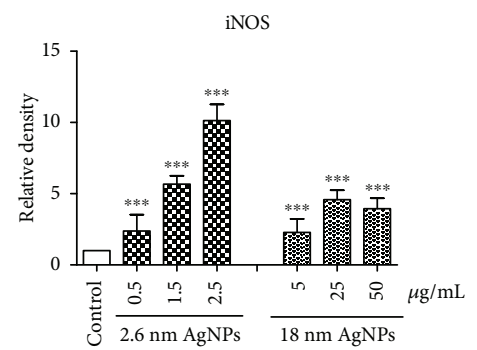

(e)

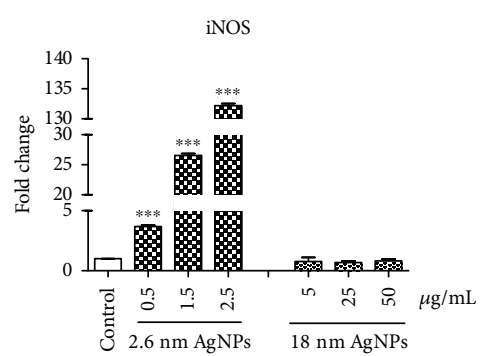

(h)

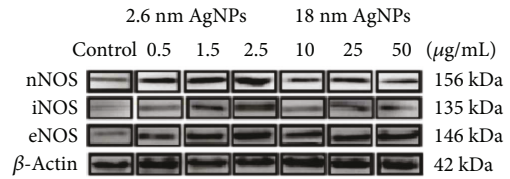

(c)

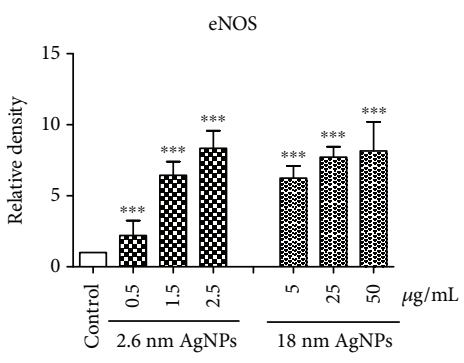

(f)

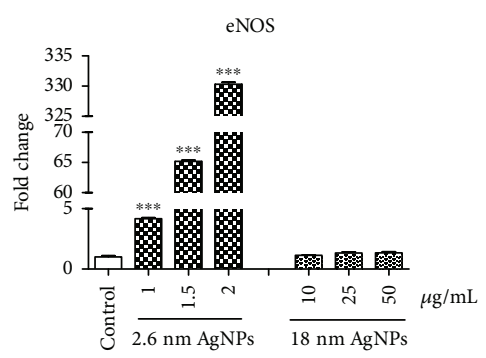

(i)

FIgURE 2: 2.6 and $18 \mathrm{~nm}$ AgNPs induced RNS generation and changes in NOS protein and mRNA level in PANC-1 cells. (a) NO. (b) NO${ }_{2}$, changes in NOS protein level: (c) representative Western blot analysis of nNOS, iNOS, and eNOS. (d) nNOS, (e) iNOS, and (f) eNOS. mRNA level of (g) nNOS, (h) iNOS, and (i) eNOS in PANC-1 cells after treatment for 24. Control (+): cells treated with LPS for $24 \mathrm{~h}$; control: untreated cells. Data are expressed as mean \pm SD of 4 independent experiments. ${ }^{*} p<0.05 ;{ }^{* * *} p<0.001$ exposed cells versus control.

level of NO was significantly augmented by $15.8 \%, 45.7 \%$, $65.3 \%, 95.8 \%$, and $98.1 \%$, respectively. An increase of NO level after $24 \mathrm{~h}$ treatment with $5 \mu \mathrm{g} / \mathrm{mL}$ of $2.6 \mathrm{~nm}$ AgNPs was 6-fold higher than after incubation with the same concentration of $18 \mathrm{~nm}$ AgNPs. Moreover, we demonstrated $2.6 \mathrm{~nm}$ and $18 \mathrm{~nm}$ AgNP-induced generation of $\mathrm{NO}_{2}$ in PANC-1 cells (see Figure 2(b)). This effect was not dependent on the concentration of AgNPs. For all used concentrations of 2.6 and $18 \mathrm{~nm} \mathrm{AgNPs,} \mathrm{the} \mathrm{NO}_{2}$ level was maintained at 2-3 nM, while positive control (treated with LPS) showed $\mathrm{NO}_{2}$ level about $7 \mathrm{nM}$.

Next, we noticed that $2.6 \mathrm{~nm}$ AgNPs induced a significant increase in iNOS, nNOS, and eNOS protein level in PANC-1 cells and $18 \mathrm{~nm}$ AgNPs induced a significant increase in eNOS and iNOS protein level (see Figures 2(d)-2(f)). Interestingly, the highest increase we observed in nNOS level (50-fold higher than control) for $3.5 \mu \mathrm{g} / \mathrm{mL} 2.6 \mathrm{~nm} \mathrm{AgNPs}$ and in eNOS protein level for $2.5 \mu \mathrm{g} / \mathrm{mL} 18 \mathrm{~nm}$ AgNPs (5fold higher than control).

Furthermore, our result showed that $2.6 \mathrm{~nm}$ AgNPs induced increasing of all NOS isoforms (iNOS, eNOS, and
nNOS) at mRNA level in a concentration-dependent manner (see Figures 2(f)-2(h)). The highest increase we observed for eNOS, which was 2-fold higher as the other isoforms. On the other hand, bigger AgNPs $(18 \mathrm{~nm})$ did not affect the level of investigated isoforms of NOS mRNA (see Figures 2(g)-2(i)).

Additionally, we focused on the determination of protein and mRNA level of selected cellular antioxidant in PANC-1 cells after treatment with AgNPs.

3.3. Impairment of Enzymatic Antioxidant Defense System in PANC-1 Cells after Treatment with AgNPs. We evaluated the protein level of selected antioxidant enzymes: SOD1, SOD2, and GPX-4. We observed a significant reduction in cytosolic and mitochondrial SOD and GPX-4 at protein level (see Figure 3 ). We noticed a statistically significant decrease of SOD1 after treatment with both 2.6 and $18 \mathrm{~nm}$ AgNPs in the entire range of used concentrations. Interestingly, bigger AgNPs induced a higher decrease than $2.6 \mathrm{~nm}$ AgNPs in SOD2 protein level, while smaller ones caused a higher decrease of SOD1 protein level. In a parallel study, we showed that $2.6 \mathrm{~nm}$ AgNPs caused a higher decrease in 
SOD1

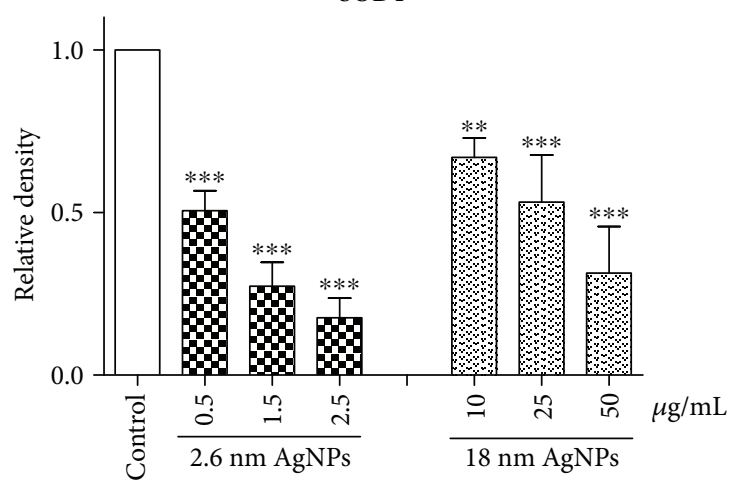

(a)

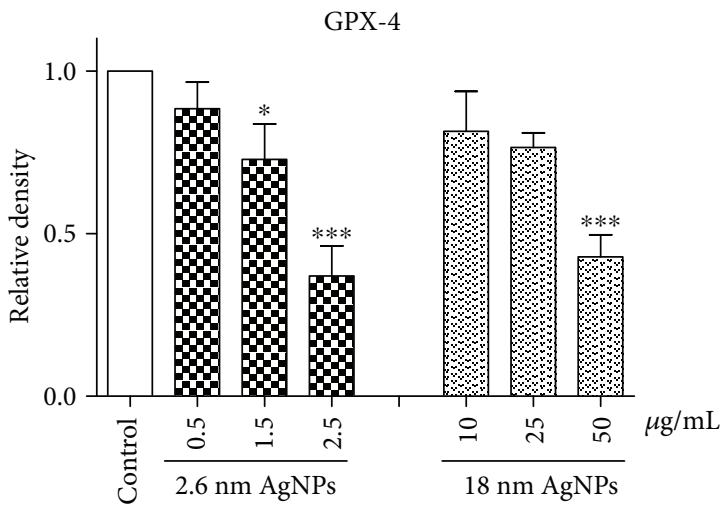

(c)
SOD2

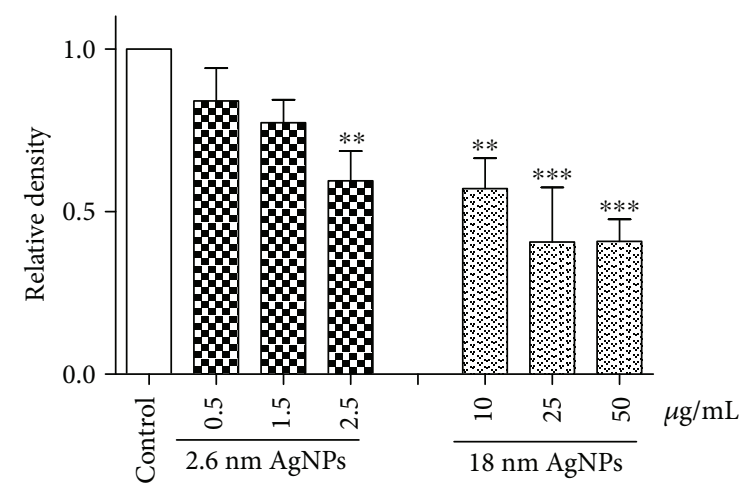

(b)

FIGURE 3: 2.6 and $18 \mathrm{~nm}$ AgNPs induced a decrease in antioxidant enzymes protein level in PANC-1 cells after treatment for $24 \mathrm{~h}$. (a) SOD1. (b) SOD2. (c) GPX-4. (d) Representative Western blot analysis of SOD1, SOD2, and GPX-4. $\beta$-actin was used as internal control. Data are mean \pm SD of 3 separate determinations. ${ }^{*} p<0.05 ;{ }^{* *} p<0.01 ;{ }^{* * *} p<0.001$ as compared with untreated cells.

SOD1, SOD2, and CAT at mRNA level after $24 \mathrm{~h}$ incubation than $18 \mathrm{~nm}$ AgNPs (see Figure 4). Moreover, after treatment PANC-1 cells with $2.6 \mathrm{~nm}$ AgNPs, we observed a lower reduction in SOD2 mRNA level than in SOD1 mRNA level, contrary to the protein level. We have not noticed a significant change in CAT mRNA level after treatment with $18 \mathrm{~nm}$ AgNPs. On the other hand, we found a significant increase in SOD3 mRNA level after treatment with $2.6 \mathrm{~nm}$ AgNPs in a concentration-dependent manner, while bigger AgNPs did not affect the expression of this SOD isoform.

Subsequently, we decided to explore more deeply the implication of oxidative and nitro-oxidative stress in AgNPs-induced pancreatic cancer cell death.

Thus, next, we have estimated the effect of AgNPs with both sizes on cell cycle in PANC-1.

3.4. Cell Cycle Distribution after Treatment PANC-1 Cells with AgNPs. After $24 \mathrm{~h}$ incubation with $2.6 \mathrm{~nm}$ and $18 \mathrm{~nm}$ AgNPs, we noticed a decrease of G0/G1 phase cell population in a concentration-dependent manner compared with control (Figure 5(a)). $24 \mathrm{~h}$ incubation with $0.5,1.5$, and $2.5 \mu \mathrm{g} / \mathrm{mL}$ of $2.6 \mathrm{~nm}$ and 25 and $50 \mu \mathrm{g} / \mathrm{mL}$ of $18 \mathrm{~nm}$ AgNPs resulted in a significantly higher percentage of cells in the S phase $(12.9 \pm 1.5 \%, 17.7 \pm 2.1 \%, 28.6 \pm 2.3 \%$, $4.6 \pm 1.6 \%$, and $23.3 \pm 2.7 \%$, resp.) than in control $(7.9 \pm$ $0.8 \%)$. Furthermore, we noticed an increase of $\mathrm{G} 2 / \mathrm{M}$ phase for cells treated with both $2.6 \mathrm{~nm}$ and $18 \mathrm{~nm}$ AgNPs at all used concentrations. Importantly, as shown in Figure 5(b) a significant increase in the percentage of cells in the sub-G1 phase was found after treatment with $2.6 \mathrm{~nm}$ AgNPs at $0.5,1.5$, and $2.5 \mu \mathrm{g} / \mathrm{mL}(25.3 \pm 0.8 \%$, $44.3 \pm 1.8 \%$, and $66 \pm 1.2 \%$, resp.) and $18 \mathrm{~nm}$ AgNPs at 10,25 , and $50 \mu \mathrm{g} / \mathrm{mL}(29.2 \pm 1.6 \%, 37.3 \pm 2.4$, and $68.2 \pm$ $2.1 \%$, resp.) in comparison with control $(1.8 \pm 1.10 \%)$.

Importantly, as shown in Figure 5(b) a significant increase in the percentage of cells in the sub-G1 phase was found after treatment with $2.6 \mathrm{~nm} \mathrm{AgNPs}$ at 0.5, 1.5, and $2.5 \mu \mathrm{g} / \mathrm{mL}(25.3 \pm 0.8 \%, 44.3 \pm 18 \%$, and $66 \pm 1.2 \%$, resp.) and $18 \mathrm{~nm}$ AgNPs at 10,25 , and $50 \mu \mathrm{g} / \mathrm{mL}(29.2 \pm 1.6 \%$, $37.3 \pm 2.4$, and $68.2 \pm 2.1 \%$, resp.) in comparison with control $(1.8 \pm 1.10 \%)$.

Afterwards, we decided to examine the effect of AgNPs on the mitochondrial membrane potential and ultrastructure of mitochondria in PANC-1 cells.

\subsection{Changes in Mitochondrial Membrane Depolarization and} Ultrastructural Alterations in PANC-1 after Treatment with AgNPs. We found that $24 \mathrm{~h}$ treatment with 2.6 and $18 \mathrm{~nm}$ AgNPs resulted in an increase of the percentage of cells with low mitochondrial membrane potential $(\Delta \psi \mathrm{m})$, compared to the untreated cells (see Figure 6) in a concentrationdependent manner. 


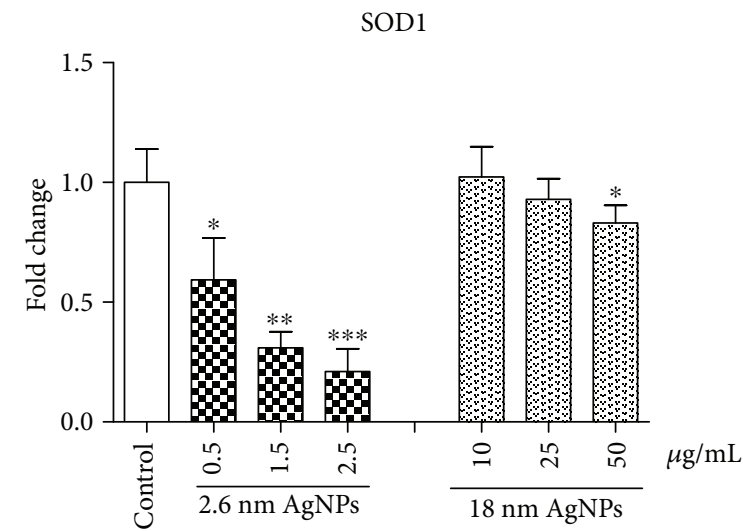

(a)

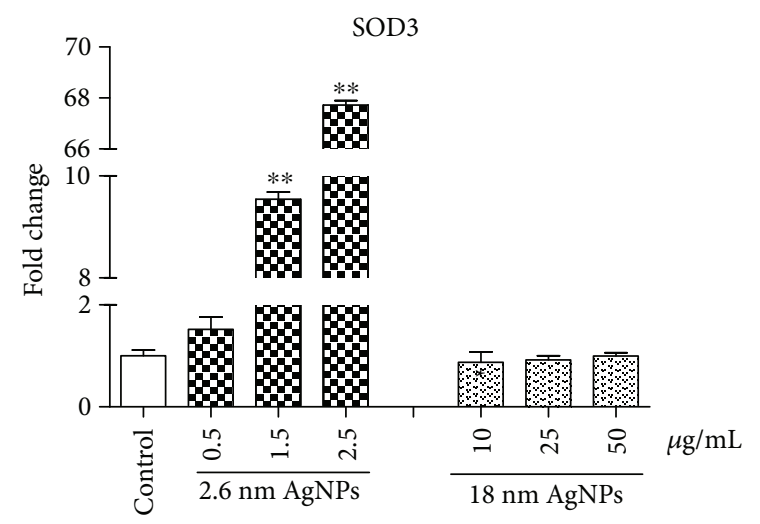

(c)

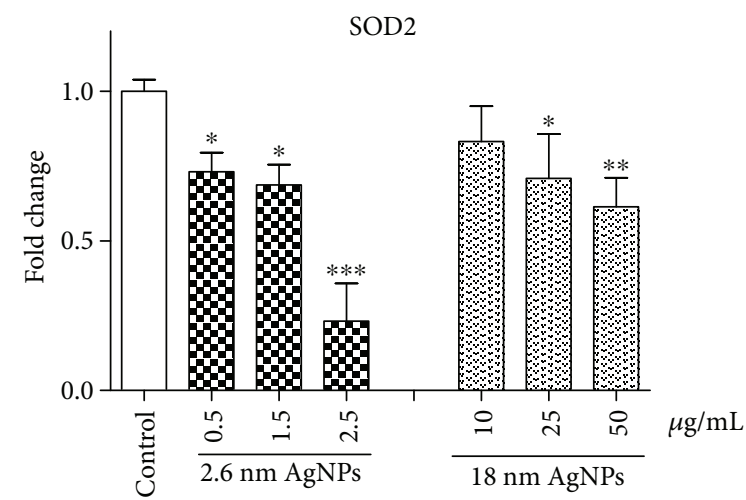

(b)

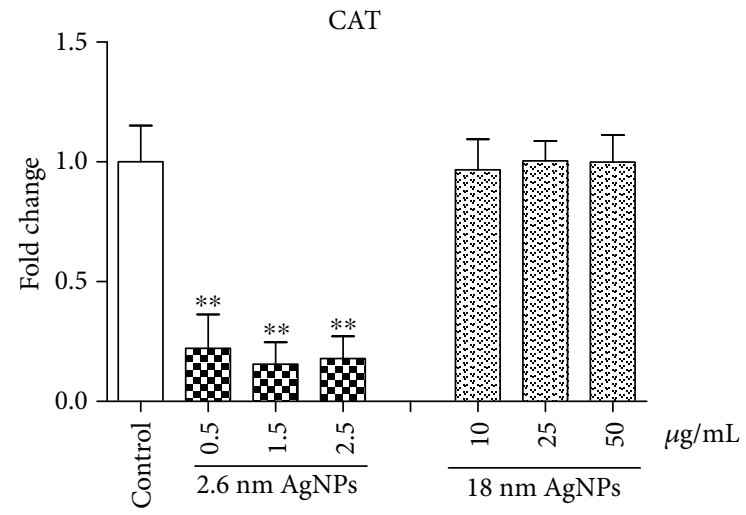

(d)

FIgURE 4: 2.6 and $18 \mathrm{~nm}$ AgNP-induced changes in antioxidant enzymes at mRNA level in PANC-1 cells after treatment for $24 \mathrm{~h}$. (a) SOD1. (b) SOD2. (c) SOD3. (d) CAT. Data are expressed as mean \pm SD of 4 independent experiments. ${ }^{*} p<0.05 ;{ }^{* *} p<0.01 ;{ }^{* * *} p<0.001$ exposed cells versus control.

This effect was accompanied by alteration of mitochondrial ultrastructure (see Figure 7). Unaltered mitochondrial ultrastructure with long, regular cristae, electron-lucent matrix, and oval-to-rod-shape were observed in a control sample (see Figure $7(\mathrm{a})$ ), cells treated with $0.5 \mu \mathrm{g} / \mathrm{mL}$ of $2.6 \mathrm{~nm} \mathrm{AgNPs} \mathrm{(see} \mathrm{Figure} \mathrm{7(b))} \mathrm{and} \mathrm{cells} \mathrm{treated} \mathrm{with} \mathrm{5,} \mathrm{10,}$ and $25 \mu \mathrm{g} / \mathrm{mL}$ of $18 \mathrm{~nm}$ AgNPs (see Figures $7(\mathrm{f})-7(\mathrm{~h})$ ). We noticed swelling of mitochondria and degradation of cristae in cells treated with $2.6 \mathrm{~nm}$ AgNPs in a concentration of $2.5 \mu \mathrm{g} / \mathrm{mL}$ (see Figures 7(c) and 7(d)). In higher concentration of $5 \mu \mathrm{g} / \mathrm{mL}$, we observed general cell degradation and nuclear condensation leading to cell death (see Figure 7(e)). Also, we observed shrinkage and condensation of mitochondria in the presence of $18 \mathrm{~nm} \mathrm{AgNPs}$ in a concentration of $50 \mu \mathrm{g} / \mathrm{mL}$ (see Figures 7(i) and 7(j)). In the highest concentration of $18 \mathrm{~nm} \mathrm{AgNPs}(100 \mu \mathrm{g} / \mathrm{mL})$, we observed cell death, accompanied by nuclear condensation and cell organelles degradation, such morphology suggested cell death (see Figures $7(\mathrm{k})$ and $7(\mathrm{j}))$.

\section{Discussion}

To assess the role of oxidative stress in AgNP-induced pancreatic cancer cell death, we designated AgNPconcentration range based on our earlier study [6] and the half maximal inhibitory concentration $\left(\mathrm{IC}_{50}\right)$ value determination, which is presented in Table 2.

Importantly, we showed a significantly higher cytotoxic effect of AgNPs on PANC-1 than nontransformed pancreatic cell. In our previous study, we have observed that 2.6 and $18 \mathrm{~nm}$ AgNPs induced mixed types of pancreatic cancer cells death [6]. In the present work, we decided to evaluate the contribution of oxidative and nitro-oxidative stress in AgNP-induced cytotoxicity against human pancreatic adenocarcinoma cells because of their important role in cancer cell death. We found that treatment of PANC-1 cells with AgNPs resulted in the enhancement of ROS production. Moreover, this increase was more significant in cancer cells than in noncancer cells of the same tissue. Similarly, Gurunathan et al. [31] documented ROS-mediated mechanism of the mitochondrial pathway of apoptosis after treatment with AgNPs in human breast cancer cells. Also, Vasanth et al. [32] noticed that AgNPs have a great anticancer potential due to selective disruption of the mitochondrial respiratory chain, which leads to the production of ROS, oxidative damage, and ultimately cell death. Edderkaoui et al. [33] showed that ROS production through activation of NADPH oxidase resulted in increased pancreatic cancer cell survival.

Moreover, we reported a significant increase of $\mathrm{NO}$ and $\mathrm{NO}_{2}$ level in PANC-1 cells after treatment with 2.6 and 


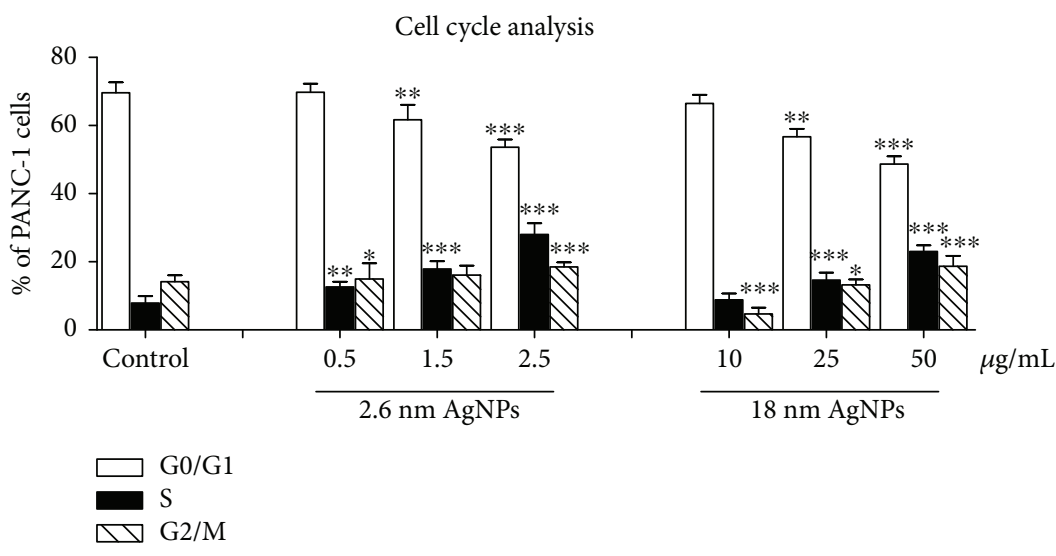

(a)

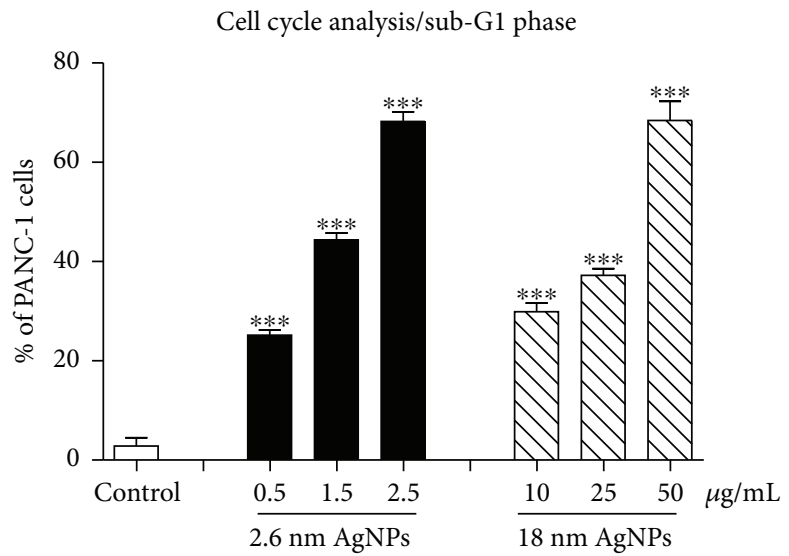

(b)

FIgure 5: The cell cycle distribution of PANC-1 cells treated with $2.6 \mathrm{~nm}$ and $18 \mathrm{~nm}$ AgNPs for $24 \mathrm{~h}$ incubation. (a) The percentage of cells in each phase (G0/G1, S, and G2/M). (b) Cell population in a sub-G1 fraction. Results are given as mean \pm SD of 3 separate determinations. ${ }^{*} p<0.05 ;{ }^{* *} p<0.01 ;{ }^{* * *} p<0.001$ as compared with untreated cells.

$18 \mathrm{~nm}$ AgNPs. Effective anticancer activity associated with increasing NO level was noticed in pancreatic, colon, and ovarian cancer cells [34-36]. Furthermore, aberrant generation or metabolism of $\mathrm{NO}$ increases nitro-oxidative stress and upregulation of the cell death mediators p53 [37]. Indeed, in our previous study, we described a significant increase in the level of $\mathrm{p} 53$ protein in PANC-1 cells after treatment with 2.6 and $18 \mathrm{~nm}$ AgNPs [6]. We also observed an increase of all investigated NOS isoforms: iNOS, eNOS, and nNOS at mRNA and protein level after $24 \mathrm{~h}$ treatment with $2.6 \mathrm{~nm}$ of AgNPs and in protein level after $24 \mathrm{~h}$ treatment with $18 \mathrm{~nm}$ AgNPs. Thus, our data suggested that 2.6 and $18 \mathrm{~nm}$ AgNPs regulated NOS protein levels by different pathways: $2.6 \mathrm{~nm}$ AgNPs regulates at the transcriptional level, whereas $18 \mathrm{~nm}$ AgNPs regulates at the translational level. Similarly, Niu et al. [38] described 1-10 nm CeO2induced increase in iNOS mRNA level in human cardiomyocytes, and González et al. [39] showed that $45 \mathrm{~nm}$ AgNPs induced increase in iNOS protein level in the rat tracheal smooth muscle. Moreover, Xue et al. [40] compared the induction of protein and mRNA iNOS level depending on the type and size of NP in primary microglia cells. They showed the highest iNOS mRNA and protein level in primary microglia cells after $24 \mathrm{~h}$ incubation with $20 \mathrm{~nm}$ $\mathrm{TiO}_{2} \mathrm{NPs}$ in comparison to $24 \mathrm{~h}$ incubation with $12 \mathrm{~nm}$ HAPNPs and $20 \mathrm{~nm} \mathrm{SiO} 2$ NPs. $20 \mathrm{~nm} \mathrm{TiO}_{2} \mathrm{NPs}$ showed a higher increase in protein than in mRNA iNOS level. On the other hand, they noticed a higher mRNA than protein iNOS level after treatment with $12 \mathrm{~nm}$ HAPNPs and $20 \mathrm{~nm}$ $\mathrm{SiO}_{2} \mathrm{NPs}$ [40]. On the other hand, under in vitro exposure, some types of NPs $\left(2.4 \mathrm{~nm}\right.$ PtNPs, 3-5 nm $\mathrm{CeO}_{2}, 13 \mathrm{~nm}$ AuNPs) have not significantly affected NOS mRNA nor protein level [41-43].

It has been documented that NO and other RNS can be synthesized by two NOS isoforms: eNOS and iNOS in human pancreatic cancer cells [44-46]. However, current research also demonstrated the significant role of nNOS increased overexpression in tumor (lung and ovarian) progression $[47,48]$. We present, to the best of our knowledge for the first time, a significant increase of nNOS protein and mRNA level in human pancreatic cancer cells. Our findings are similar to those of Begum et al. [48], who also noticed that an increase in nNOS and iNOS expression lead to RNS production, nitro-oxidative stress, and human lung cancer cells death. Chakraborty et al. [49] observation proved a significant increase of iNOS protein level and NO level in 


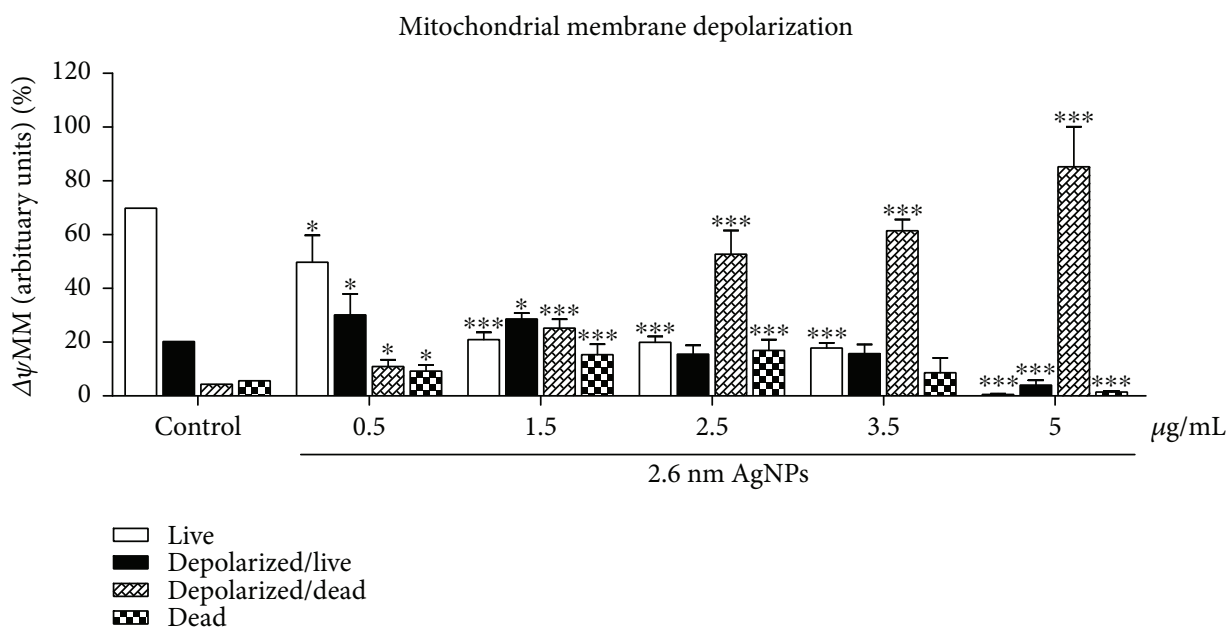

(a)

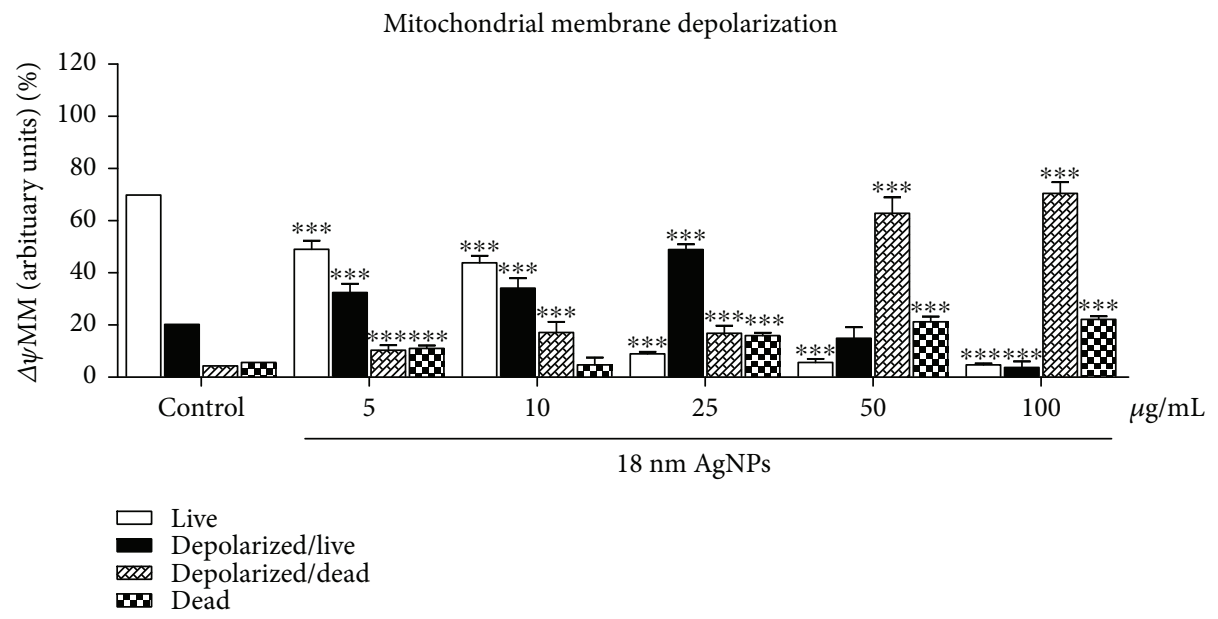

(b)

FIGURE 6: (a) $2.6 \mathrm{~nm}$ and (b) $18 \mathrm{~nm}$ AgNPs induced changes in mitochondrial membrane potential of PANC-1 cells after $24 \mathrm{~h}$ treatment. Changes in mitochondrial membrane potential and induction of cell death were determined using the Muse Cell Analyzer. Values are the mean \pm SD of 3 independent experiments. ${ }^{*} p<0.05 ;{ }^{* * *} p<0.001$ exposed cells versus untreated control.

murine fibrosarcoma cells after treatment with $10 \mathrm{~nm}$ AgNPs. Xie et al. [50] showed that overexpression of iNOS mRNA level reduced the survival and metastatic potential of a murine melanoma cell line. Also, Jadeski et al. [51] described that iNOS expression in human pancreatic cancer cells is positively correlated with apoptosis. On the other hand, an increase in iNOS expression can affect the stimulation of angiogenesis and tumor progression [52]. However, Kong et al. [44] have not observed a significant role of iNOS in pancreatic cancer cells proliferation and regulation of angiogenesis, which can play a crucial role in tumor growth and metastasis. Interestingly, Díte et al. [46] suggested that eNOS have limited role in the normal physiology of pancreatic cells, while aberration in eNOS expression may play a significant role in cancer cells progression and programmed cell death $[22,46]$. On the other hand, the antitumor effects of eNOS inhibition in pancreatic cancer cells were observed [45]. Gratton et al. [53] showed that inhibition of eNOS activity decreases tumor vascular permeability and tumor growth in hepatocarcinoma and lung carcinoma xenograft models.

Furthermore, we demonstrated that AgNP-induced generation of ROS and RNS in PANC-1 cells was associated with a significant disturbance of antioxidant enzymes at protein and mRNA level. It has been indicated that ROS and/or RNS production and antioxidant system impairment lead to programmed cancer cell death $[21,54]$. Ahamed et al. [55] reported that $\mathrm{ZnONPs}$ significantly decreased the antioxidant level in hepatoma cells and triggered apoptosis. Arora et al. [56] and Jin et al. [57] showed a reduced level of SOD after treatment of human skin carcinoma and human fibrosarcoma with 7-20 nm AgNPs leading to apoptosis. Moreover, Asadpour et al. [58] noticed that $<100 \mathrm{~nm}$ $\mathrm{ZrO}_{2} \mathrm{NPs}$-induced decrease in GPX activity in rat pheochromocytoma, and mouse neuroblastoma cells were related to genotoxic and cytotoxic effect. In PANC-1 cells, we noticed a decreased level of SOD1 protein and mRNA after treatment with $2.6 \mathrm{~nm}$ and $18 \mathrm{~nm}$ AgNPs. Papa et al. [24] found that 


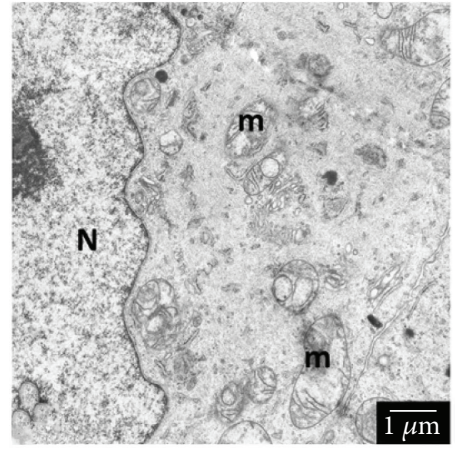

(a)

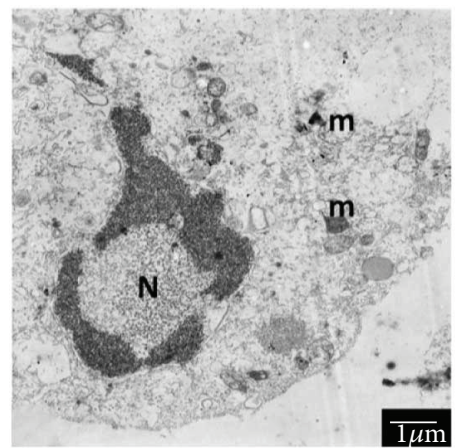

(e)

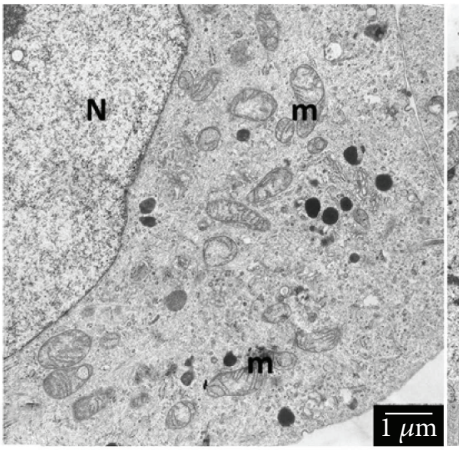

(b)

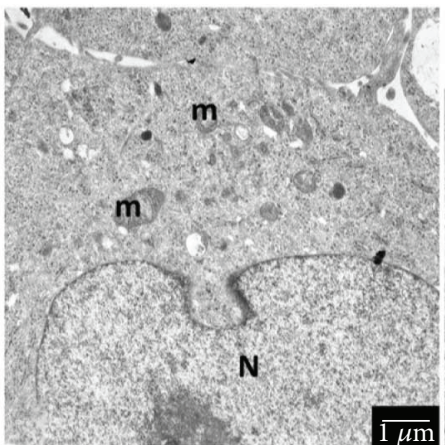

(f)

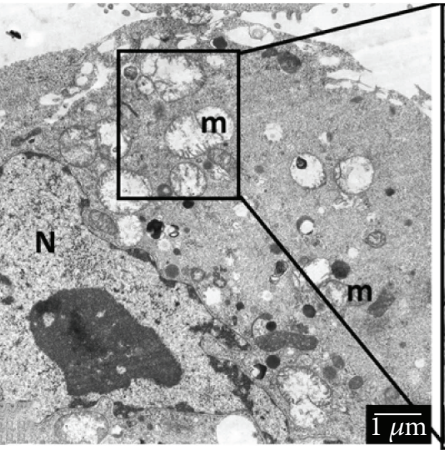

(c)

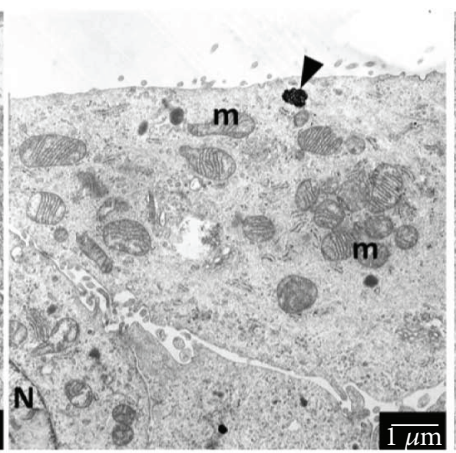

(g)

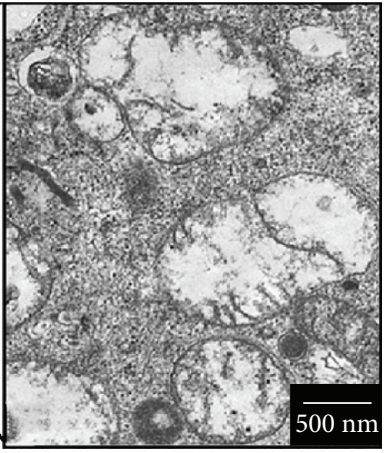

(d)

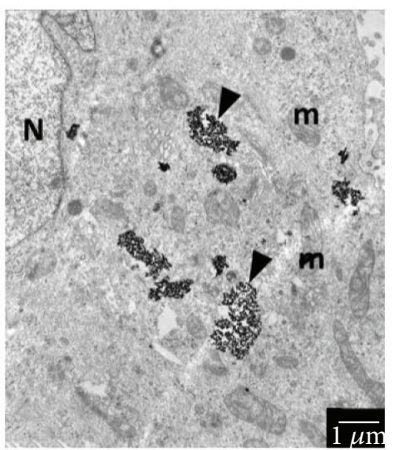

(h)

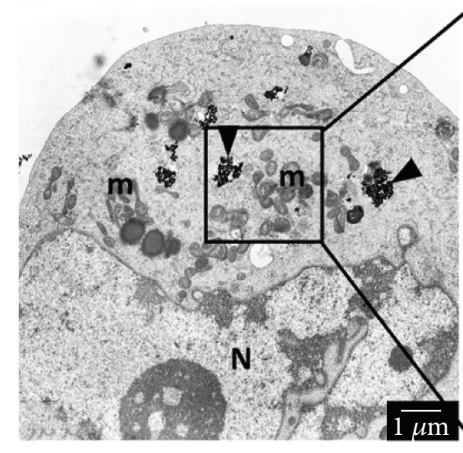

(i)

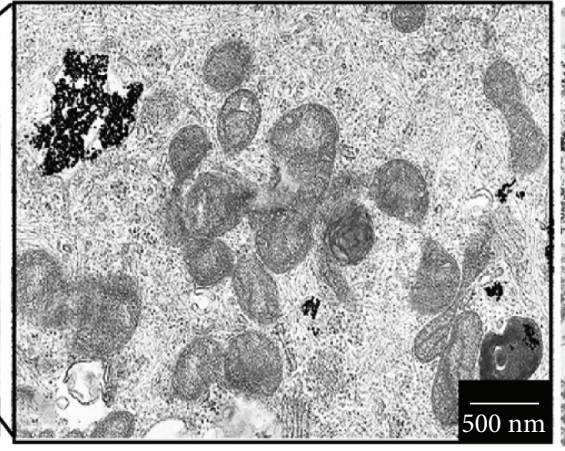

(j)

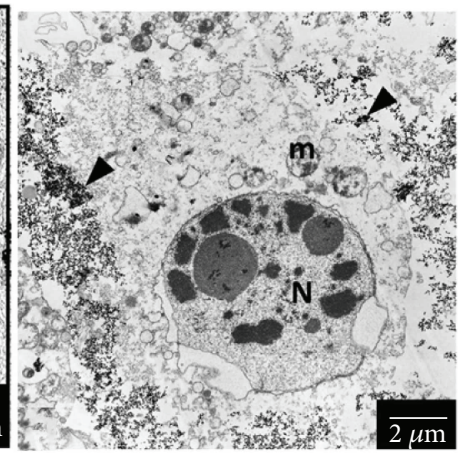

(k)

FIgURE 7: The ultrastructure of mitochondria in PANC-1 cells after treatment with $2.6 \mathrm{~nm}$ and $18 \mathrm{~nm}$ AgNPs for $24 \mathrm{~h}$. (a) untreated PANC-1 cells. (b, c/d, e) cells treated with $2.6 \mathrm{~nm} \mathrm{AgNPs}$ at concentrations of $0.5,2.5$, and $5 \mu \mathrm{g} / \mathrm{mL}$, respectively. (f, g, h, i/j, k) cells treated with $18 \mathrm{~nm}$ AgNPs at concentrations of 5, 10, 25, 50, and $100 \mu \mathrm{g} / \mathrm{mL}$, respectively. N: nucleus; m: mitochondria; arrow: AgNPs. Magnifications: (a-h) $\times 6000$; (i) $\times 5000$; (k) $\times 4000$. Scale bars: $(\mathrm{a}-\mathrm{c})$ and $(\mathrm{e}-\mathrm{i}) 1 \mu \mathrm{m}$; (k) $2 \mu \mathrm{m}$; (d, j) $500 \mathrm{~nm}$.

TABLE 2: IC $_{50}$ values obtained after treatment of PANC-1 and hTERT-HPNE cells with 2.6 and $18 \mathrm{~nm}$ AgNPs.

\begin{tabular}{lcccc}
\hline & $\begin{array}{c}\mathrm{IC}_{50} \text { from LDH } \\
(\mu \mathrm{g} / \mathrm{mL})\end{array}$ & $\begin{array}{c}\mathrm{IC}_{50} \text { from MTT } \\
(\mu \mathrm{g} / \mathrm{mL})\end{array}$ & $\begin{array}{c}\mathrm{IC}_{50} \text { from LDH } \\
(\mu \mathrm{g} / \mathrm{mL})\end{array}$ & $\begin{array}{c}\mathrm{IC}_{50} \text { from } \text { MTT } \\
(\mu \mathrm{g} / \mathrm{mL})\end{array}$ \\
\hline PANC-1 & 3.19 & 1.67 & 56.46 & 26.81 \\
hTERT-HPNE & 8.06 & 3.74 & 160.3 & 58.46 \\
& & $2.6 \mathrm{~nm} \mathrm{AgNPs}$ & & $18 \mathrm{~nm} \mathrm{AgNPs}$ \\
\hline
\end{tabular}

The inhibitory concentration, $\mathrm{IC}_{50}$, was calculated from the following equation: $\log$ (inhibitor) versus responses curve using the GraphPad Prism 5 program.

inhibition of SOD1 activity in breast cancer cells (MCF-7) leads to a drastic alteration in the morphology of the mitochondria associated with increased fragmentation and swelling of the matrix. This effect was not observed in the nonmalignant breast epithelial cells line (MCF-10A). Glasauer et al. [59] described that SOD1 inhibition drastically 
reduces lung carcinoma cells proliferation. Moreover, Peng et al. [60] suggested that the mechanism by which SOD1 inhibitors cause cell death is likely through a combination of the regulated mechanism (apoptosis) and unregulated mechanism (oxidative damage to the organelles). In addition, we identified 2.6 and $18 \mathrm{~nm}$ AgNPs induced a decrease in SOD2 protein and mRNA level. It has been known that in the mitochondrial matrix, the manganese dismutase SOD2 acts as a major antioxidant enzyme. Mn-SOD low activity and expression have also been reported in certain colorectal carcinomas and pancreatic cancer cells [61]. Ahamed et al. [55] noticed a decrease of SOD1 and SOD2 protein level and activity in human alveolar adenocarcinoma after treatment with $28-38 \mathrm{~nm}$ Zn-doped $\mathrm{TiO}_{2} \mathrm{NPs}$. Moreover, we showed that treatment of PANC-1 cells with $2.6 \mathrm{~nm}$ AgNPs resulted in an increase of SOD3 mRNA level, which catalyzes the dismutation of superoxide in the extracellular environment [35]. SOD3 is highly cell-type specific and can be found most abundantly in the pancreas, lung, kidney, and vasculature [34-36]. It has been known that loss of SOD3 level could contribute to aggressive and refractory nature of pancreatic ductal adenocarcinoma. Hayano et al. [62] proved that overexpression of EcSOD in PDA cell lines resulted in decreased invasiveness, slower growth, and peritoneal metastasis of pancreatic cancer cells.

Furthermore, we noticed decreased mRNA level of CAT in PANC-1 cells after treatment with smaller AgNPs. Pramanik et al. [63] showed that overexpression of CAT by transient transfection protected the human squamous carcinoma cells from capsaicin-mediated ROS generation and apoptosis. On the other hand, Glorieux et al. [64] showed that CAT overexpression leads to a less aggressive phenotype and an altered response to chemotherapy of breast cancer cells.

In addition, in PANC-1 cells, we observed a significant reduction of GPX-4 protein level after treatment with 2.6 and $18 \mathrm{~nm}$ AgNPs. GPX-4 is considered to be the primary enzymatic defense mechanism against oxidative damage to cellular membranes [65]. Yang et al. [66] reported that GPX-4 is an essential regulator of programmed cancer cell death (ferroptotic). Besides, Hangauer et al. [67] suggested that silencing of GPX-4 may turn out a new strategy to prevent acquired drug resistance. This is related to the demonstrated high resistance of melanoma cells (A375) in a high mesenchymal therapy-resistant to GPX-4 dependence. Loss of GPX-4 function results in selective ferroptotic cell death and prevents tumor relapse in mice.

Summarizing, Glasauer et al. [59] suggested that the reduction of antioxidant enzymes (SOD1, SOD2, GPX-4, and CAT) level induced apoptosis by the activation of p38 and a decrease in the antiapoptotic factor MCL1 caused by elevation in ROS level in lung cancer cells.

Furthermore, we observed that AgNPs caused an increase in PANC-1 cells population with low mitochondrial membrane potential $(\Delta \psi \mathrm{m})$ in a concentration-dependent manner. Teodoro et al. [68] noticed a size-dependent effect of 40 and $80 \mathrm{~nm}$ AgNPs on the activation of the mitochondrial permeability transition. Interestingly, a stronger effect was demonstrated for smaller $(40 \mathrm{~nm})$ AgNPs. Moreover, it has been proved that the disruption of mitochondrial membrane potential $(\Delta \psi \mathrm{m})$ and opening mitochondrial membrane pores are associated with apoptosis or other forms of programmed cell death $[69,70]$. Kim et al. [71] indicated that the mitochondrial membrane permeabilization leads to the release of apoptogenic factors and next to apoptosis of prostate cancer cells. Jung et al. [72] described the model of apoptotic pancreatic cancer cells death inducing by mitochondrial membrane depolarization and caspase activation. Besides, some reports showed the harmful effect of nanostructures on mitochondrial function in the lung and kidney cancer cells [73]. These results suggest that AgNP-induced mitochondrial-mediated PANC-1 cell death could occur on the path to apoptosis. Furthermore, some studies described a close link between NP-induced ROS elevation, cell cycle arrested, and mitochondrial-mediated apoptosis [23, 74]. In our study, we noticed a significant increase in sub-G1 population induced by AgNPs, and this observation could be related to PANC-1 apoptotic cell death, which we documented previously [26]. A relation between an increase of sub-G1 hypodiploid cells population and mitochondrialmediated apoptosis has been described [75, 76]. Similarly, Zhu et al. [75] described cell cycle arrested in sub-G1 phase in human liver cancer cells treated with $2 \mathrm{~nm}$ AgNPs. Furthermore, $2.6 \mathrm{~nm}$ AgNP-induced increase of $\mathrm{S}$ phase in PANC-1 cells could also trigger apoptosis [77]. Salehi et al. [78] reported that chitosan, a semisynthetic biobased polysaccharide, promotes $S$ phase cell cycle arrest and ROSmediated apoptosis in triple-negative breast cancer cells. On the other hand, $\mathrm{Hu}$ et al. [79] described a significant decrease of $S$ phase and apoptosis pathway in breast cancer cells after treatment with an alcohol extract of Ganoderma lucidum. Interestingly, Panzarini et al. [80] suggested that AgNPs may be exploited for the development of novel antiproliferative treatment in cancer therapy because of decreasing Hela cell viability, arresting the cell cycle in $\mathrm{S}$, G2/M phase, and increasing sub-G1 population. Zhang et al. [76] reported that AgNP-induced human nasopharyngeal carcinoma and liver cancer cells arrest at G2/M or G1 cell cycle phase resulted in increased radiation sensitivity of tumors. In our study, we noticed that AgNPs treatment leads to cell cycle arrest in S, G2/M-phase in PANC-1 cells. However, Li et al. [81] reported that AgNPs inhibited cell cycle in the G2/M phase in glioblastoma U251 cells, and it could be associated with repair of cell oxidative damage.

Our previous work showed cellular uptake of 2.6 and $18 \mathrm{~nm}$ AgNPs in PANC-1 cells and their localization in the cytosol [6]. During this study, we found that AgNPinduced changes in biochemical parameters were associated with ultrastructural alteration of pancreatic cancer cells link to oxidative stress, such as swelling of mitochondria, degradation of cristae, shrinkage, and condensation of mitochondria as well as nuclear condensation [60, 82-84]. These changes have been also described as characteristic of apoptosis via oxidative stress in in vitro models $[84,85]$ and are consistent with our previous study [26].

Considering all the information above, our results indicated that induction of ROS and RNS generation along with disturbance in the enzymatic antioxidant system is 
implicated in the cytotoxicity activity of AgNPs against pancreatic cancer cells.

\section{Conclusions}

To summarize, we observed that exposure to both $2.6 \mathrm{~nm}$ and $18 \mathrm{~nm}$ AgNPs leads to an increased production of ROS and RNS in PANC-1 cells. We found upregulation of mRNA and protein level of NOS family, and for the first time, we have described a significant increase of nNOS in pancreatic cancer cell death. This effect was associated with arrested PANC-1 cells in sub-G1cell cycle phase related to programmed cell death, low level of mitochondrial membrane potential, and changes in mitochondrial ultrastructure, typical for oxidative damage. Moreover, we detected AgNPinduced disturbance of antioxidant system (SOD1, SOD2, GPX-4, CAT, and SOD3) in pancreatic cancer cells. In conclusion, we confirmed our hypothesis that oxidative and nitro-oxidative mechanism is implicated in AgNP-induced human pancreatic ductal adenocarcinoma cell death. Our results can be used in developing new strategies for pancreatic cancer nanotherapy.

\section{Data Availability}

The data used to support the findings of this study are included within the article (Figures 1-7). Previously reported, our data (Table 1) were used to support this study and are available at (https://doi.org/10.18632/oncotarget. 22563). These prior studies (and datasets) are cited at relevant places within the text as references [12].

\section{Conflicts of Interest}

The authors declare that there is no conflict of interest regarding the publication of this paper.

\section{Acknowledgments}

This study was supported by the Grants 01-0268/08/259 and St-46 from the Medical University of Gdansk, Poland, and the Grant 2017/26/M/NZ7/01030 from National Science Centre of Poland.

\section{References}

[1] S. Yang and A. C. Kimmelman, "A critical role for autophagy in pancreatic cancer,” Autophagy, vol. 7, no. 8, pp. 912-913, 2011.

[2] D. Yadav and A. B. Lowenfels, "The epidemiology of pancreatitis and pancreatic cancer," Gastroenterology, vol. 144, no. 6, pp. 1252-1261, 2013.

[3] G. M. Vlăsceanu, Ş. Marin, R. E. Țiplea et al., "Silver nanoparticles in cancer therapy," Nanobiomaterials in Cancer Therapy, vol. 7, pp. 29-56, 2016.

[4] M. Jeyaraj, G. Sathishkumar, G. Sivanandhan et al., "Biogenic silver nanoparticles for cancer treatment: an experimental report," Colloids and Surfaces B: Biointerfaces, vol. 106, pp. 86-92, 2013.
[5] H. Sharma, P. K. Mishra, S. Talegaonkar, and B. Vaidya, "Metal nanoparticles: a theranostic nanotool against cancer," Drug Discovery Today, vol. 20, no. 9, pp. 1143-1151, 2015.

[6] E. Zielinska, A. Zauszkiewicz-Pawlak, M. Wojcik, and I. Inkielewicz-Stepniak, "Silver nanoparticles of different sizes induce a mixed type of programmed cell death in human pancreatic ductal adenocarcinoma," Oncotarget, vol. 9, no. 4, pp. 4675-4697, 2018.

[7] X.-F. Zhang and S. Gurunathan, "Combination of salinomycin and silver nanoparticles enhances apoptosis and autophagy in human ovarian cancer cells: an effective anticancer therapy," International Journal of Nanomedicine, vol. 11, no. 17, pp. 3655-3675, 2016.

[8] A. R. Mishra, J. Zheng, X. Tang, and P. L. Goering, "Silver nanoparticle-induced autophagic-lysosomal disruption and NLRP3-inflammasome activation in HepG2 cells is sizedependent," Toxicological Sciences, vol. 150, no. 2, pp. 473487, 2016.

[9] S. Kim, J. E. Choi, J. Choi et al., "Oxidative stress-dependent toxicity of silver nanoparticles in human hepatoma cells," Toxicology In Vitro, vol. 23, no. 6, pp. 1076-1084, 2009.

[10] M. F. Rahman, J. Wang, T. A. Patterson et al., "Expression of genes related to oxidative stress in the mouse brain after exposure to silver-25 nanoparticles," Toxicology Letters, vol. 187, no. 1, pp. 15-21, 2009.

[11] H. Wiseman and B. Halliwell, "Damage to DNA by reactive oxygen and nitrogen species: role in inflammatory disease and progression to cancer," Biochemical Journal, vol. 313, no. 1, pp. 17-29, 1996.

[12] S. Kotamraju, E. A. Konorev, J. Joseph, and B. Kalyanaraman, "Doxorubicin-induced apoptosis in endothelial cells and cardiomyocytes is ameliorated by nitrone spin traps and ebselen. Role of reactive oxygen and nitrogen species," The Journal of Biological Chemistry, vol. 275, no. 43, pp. 33585-33592, 2000.

[13] C. Gorrini, I. S. Harris, and T. W. Mak, "Modulation of oxidative stress as an anticancer strategy," Nature Reviews Drug Discovery, vol. 12, no. 12, pp. 931-947, 2013.

[14] K. Apel and H. Hirt, "Reactive oxygen species: metabolism, oxidative stress, and signal transduction," Annual Review of Plant Biology, vol. 55, no. 1, pp. 373-399, 2004.

[15] I. Kruman, A. J. Bruce-Keller, D. Bredesen, G. Waeg, and M. P. Mattson, "Evidence that 4-hydroxynonenal mediates oxidative stress-induced neuronal apoptosis," Journal of Neuroscience, vol. 17, no. 13, pp. 5089-5100, 1997.

[16] I. Kim, S. Rodriguez-Enriquez, and J. J. Lemasters, "Selective degradation of mitochondria by mitophagy," Archives of Biochemistry and Biophysics, vol. 462, no. 2, pp. 245-253, 2007.

[17] J. Lee, S. Giordano, and J. Zhang, “Autophagy, mitochondria and oxidative stress: cross-talk and redox signalling," Biochemical Journal, vol. 441, no. 2, pp. 523-540, 2012.

[18] S. Prasad, S. C. Gupta, and A. K. Tyagi, "Reactive oxygen species (ROS) and cancer: role of antioxidative nutraceuticals," Cancer Letters, vol. 387, pp. 95-105, 2017.

[19] S. Reuter, S. C. Gupta, M. M. Chaturvedi, and B. B. Aggarwal, "Oxidative stress, inflammation, and cancer: how are they linked?," Free Radical Biology \& Medicine, vol. 49, no. 11, pp. 1603-1616, 2011.

[20] G. Waris and H. Ahsan, "Reactive oxygen species: role in the development of cancer and various chronic conditions," Journal of Carcinogenesis, vol. 5, no. 1, pp. 14-15, 2006. 
[21] A. Manke, L. Wang, and Y. Rojanasakul, "Mechanisms of nanoparticle-induced oxidative stress and toxicity," BioMed Research International, vol. 2013, Article ID 942916, 15 pages, 2013.

[22] X.-F. Zhang, W. Shen, and S. Gurunathan, "Silver nanoparticle-mediated cellular responses in various cell lines: an in vitro model," International Journal of Molecular Sciences, vol. 17, no. 10, pp. 1-26, 2016.

[23] L. Papa, G. Manfredi, and D. Germain, "SOD1, an unexpected novel target for cancer therapy," Genes \& Cancer, vol. 5, no. 1-2, pp. 15-21, 2014.

[24] L. Papa, M. Hahn, E. L. Marsh, B. S. Evans, and D. Germain, "SOD2 to SOD1 switch in breast cancer," Journal of Biological Chemistry, vol. 289, no. 9, pp. 5412-5416, 2014.

[25] E. Zielinska, C. Tukaj, M. W. Radomski, and I. InkielewiczStepniak, "Molecular mechanism of silver nanoparticlesinduced human osteoblast cell death: protective effect of inducible nitric oxide synthase inhibitor," PLoS One, vol. 11, no. 10, article e0164137, 2016.

[26] I. Inkielewicz-Stepniak, M. J. Santos-Martinez, C. Medina, and M. W. Radomski, "Pharmacological and toxicological effects of co-exposure of human gingival fibroblasts to silver nanoparticles and sodium fluoride," International Journal of Nanomedicine, vol. 9, pp. 1677-1687, 2014.

[27] D. Jacewicz, A. Łapińska, A. Dąbrowska, A. Figarski, M. Woźniak, and L. Chmurzyński, "Reactions of $\mathrm{NO}_{2}$ with chromium(III) complexes with histamine and pyridoxamine ligands studied by the stopped-flow technique," Analytical Biochemistry, vol. 350, no. 2, pp. 256-262, 2006.

[28] A. Dąbrowska, D. Jacewicz, A. Łapińska et al., "Pivotal participation of nitrogen dioxide in L-arginine induced acute necrotizing pancreatitis: protective role of superoxide scavenger 4-OH-TEMPO," Biochemical and Biophysical Research Communications, vol. 326, no. 2, pp. 313-320, 2005.

[29] M. M. Bradford, "A rapid and sensitive method for the quantitation of microgram quantities of protein utilizing the principle of protein-dye binding," Analytical Biochemistry, vol. 72 , no. $1-2$, pp. 248-254, 1976.

[30] "MuseTM MitoPotential Kit user's guide," http://www. merckmillipore.com/PL/pl/product/Muse-Mitopotential-AssayKit, MM_NF-MCH100110\#anchor_UG,13.10.2017.

[31] S. Gurunathan, J. Raman, S. N. Abd Malek, P. A. John, and S. Vikineswary, "Green synthesis of silver nanoparticles using Ganoderma neo-japonicum Imazeki: a potential cytotoxic agent against breast cancer cells," International Journal of Nanomedicine, vol. 8, pp. 4399-4413, 2013.

[32] K. Vasanth, K. Ilango, R. MohanKumar, A. Agrawal, and G. P. Dubey, "Anticancer activity of Moringa oleifera mediated silver nanoparticles on human cervical carcinoma cells by apoptosis induction," Colloids and Surfaces B: Biointerfaces, vol. 117, pp. 354-359, 2014.

[33] M. Edderkaoui, P. Hong, E. C. Vaquero et al., "Extracellular matrix stimulates reactive oxygen species production and increases pancreatic cancer cell survival through 5lipoxygenase and NADPH oxidase," American Journal of Physiology-Gastrointestinal and Liver Physiology, vol. 289, no. 6, pp. G1137-G1147, 2005.

[34] M. L. T. Teoh, W. Sun, B. J. Smith, L. W. Oberley, and J. J. Cullen, "Modulation of reactive oxygen species in pancreatic cancer," Clinical Cancer Research, vol. 13, no. 24, pp. 74417450, 2007.
[35] I. N. Zelko, T. J. Mariani, and R. J. Folz, "Superoxide dismutase multigene family: a comparison of the CuZn-SOD (SOD1), Mn-SOD (SOD2), and EC-SOD (SOD3) gene structures, evolution, and expression," Free Radical Biology \& Medicine, vol. 33, no. 3, pp. 337-349, 2002.

[36] M. L. T. Teoh, M. P. Fitzgerald, L. W. Oberley, and F. E. Domann, "Overexpression of extracellular superoxide dismutase attenuates heparanase expression and inhibits breast carcinoma cell growth and invasion," Cancer Research, vol. 69, no. 15, pp. 6355-6363, 2009.

[37] M. L. T. Teoh-Fitzgerald, M. P. Fitzgerald, T. J. Jensen, B. W. Futscher, and F. E. Domann, "Genetic and epigenetic inactivation of extracellular superoxide dismutase promotes an invasive phenotype in human lung cancer by disrupting ECM homeostasis," Molecular Cancer Research, vol. 10, no. 1, pp. 40-51, 2012.

[38] J. Niu, K. Wang, and P. E. Kolattukudy, "Cerium oxide nanoparticles inhibits oxidative stress and nuclear factor- $\kappa \mathrm{B}$ activation in H9c2 cardiomyocytes exposed to cigarette smoke extract," The Journal of Pharmacology and Experimental Therapeutics, vol. 338, no. 1, pp. 53-61, 2011.

[39] C. González, S. Salazar-García, G. Palestino et al., "Effect of 45 $\mathrm{nm}$ silver nanoparticles (AgNPs) upon the smooth muscle of rat trachea: role of nitric oxide," Toxicology Letters, vol. 207, no. 3, pp. 306-313, 2011.

[40] Y. Xue, J. Wu, and J. Sun, "Four types of inorganic nanoparticles stimulate the inflammatory reaction in brain microglia and damage neurons in vitro," Toxicology Letters, vol. 214, no. 2, pp. 91-98, 2012.

[41] M. U. Rehman, Y. Yoshihisa, Y. Miyamoto, and T. Shimizu, "The anti-inflammatory effects of platinum nanoparticles on the lipopolysaccharide-induced inflammatory response in RAW 264.7 macrophages," Inflammation Research, vol. 61, no. 11, pp. 1177-1185, 2012.

[42] S. M. Hirst, A. S. Karakoti, R. D. Tyler, N. Sriranganathan, S. Seal, and C. M. Reilly, "Anti-inflammatory properties of cerium oxide nanoparticles," Small, vol. 5, no. 24, pp. 2848 2856, 2009.

[43] W. S. Cho, M. Cho, J. Jeong et al., "Acute toxicity and pharmacokinetics of 13 nm-sized PEG-coated gold nanoparticles," Toxicology and Applied Pharmacology, vol. 236, no. 1, pp. 16-24, 2009.

[44] G. Kong, E. K. Kim, W. S. Kim et al., "Inducible nitric oxide synthase (iNOS) immunoreactivity and Its relationship to cell proliferation, apoptosis, angiogenesis, clinicopathologic characteristics, and patient survival in pancreatic cancer," International Journal of Pancreatology, vol. 29, no. 3, pp. 133-140, 2001.

[45] B. L. Lampson, S. D. Kendall, B. B. Ancrile et al., "Targeting eNOS in pancreatic cancer," Cancer Research, vol. 72, no. 17, pp. 4472-4482, 2012.

[46] P. Díte, M. Hermanová, J. Trna et al., "The role of chronic inflammation: chronic pancreatitis as a risk factor of pancreatic cancer," Digestive Diseases, vol. 30, no. 3, pp. 277-283, 2012.

[47] B. Lewko, A. Zółtowska, J. Stepiński et al., "Nitric oxide synthase type 1 expression in human lung cancer and its relation to p 53," Medical Science Monitor, vol. 7, no. 2, pp. 218-221, 2001.

[48] A. N. Begum, J. S. Aguilar, L. Elias, and Y. Hong, "Silver nanoparticles exhibit coating and dose-dependent neurotoxicity in glutamatergic neurons derived from human embryonic stem cells," Neurotoxicology, vol. 57, pp. 45-53, 2016. 
[49] B. Chakraborty, R. Pal, M. Ali et al., "Immunomodulatory properties of silver nanoparticles contribute to anticancer strategy for murine fibrosarcoma," Cellular \& Molecular Immunology, vol. 13, no. 2, pp. 191-205, 2016.

[50] K. Xie, S. Huang, Z. Dong et al., "Transfection with the inducible nitric oxide synthase gene suppresses tumorigenicity and abrogates metastasis by $\mathrm{K}-1735$ murine melanoma cells," The Journal of Experimental Medicine, vol. 181, no. 4, pp. 1333-1343, 1995.

[51] L. C. Jadeski and P. K. Lala, "Nitric oxide synthase inhibition by $N^{\mathrm{G}}$-nitro-L-arginine methyl ester inhibits tumor-induced angiogenesis in mammary tumors," The American Journal of Pathology, vol. 155, no. 4, pp. 1381-1390, 1999.

[52] F. Vannini, K. Kashfi, and N. Nath, "The dual role of iNOS in cancer," Redox Biology, vol. 6, pp. 334-343, 2015.

[53] J. P. Gratton, M. I. Lin, J. Yu et al., "Selective inhibition of tumor microvascular permeability by cavtratin blocks tumor progression in mice," Cancer Cell, vol. 4, no. 1, pp. 31-39, 2003.

[54] J. K. Tee, C. N. Ong, B. H. Bay, H. K. Ho, and D. T. Leong, "Oxidative stress by inorganic nanoparticles," Wiley Interdisciplinary Reviews: Nanomedicine and Nanobiotechnology, vol. 8, no. 3, pp. 414-438, 2016.

[55] M. Ahamed, M. J. Akhtar, M. Raja et al., "ZnO nanorodinduced apoptosis in human alveolar adenocarcinoma cells via $\mathrm{p} 53$, survivin and $\mathrm{Bax} / \mathrm{Bcl}-2$ pathways: role of oxidative stress," Nanomedicine, vol. 7, no. 6, pp. 904-913, 2011.

[56] S. Arora, J. Jain, J. M. Rajwade, and K. M. Paknikar, "Cellular responses induced by silver nanoparticles: in vitro studies," Toxicology Letters, vol. 179, no. 2, pp. 93-100, 2008.

[57] C. Y. Jin, B. S. Zhu, X. F. Wang, and Q. H. Lu, "Cytotoxicity of titanium dioxide nanoparticles in mouse fibroblast cells," Chemical Research in Toxicology, vol. 21, no. 9, pp. 18711877, 2008.

[58] E. Asadpour, H. R. Sadeghnia, A. Ghorbani, M. Sedaghat, and M. T. Boroushaki, "Oxidative stress-mediated cytotoxicity of zirconia nanoparticles on PC12 and N2a cells," Journal of Nanoparticle Research, vol. 18, no. 1, p. 14, 2016.

[59] A. Glasauer, L. A. Sena, L. P. Diebold, A. P. Mazar, and N. S. Chandel, "Targeting SOD1 reduces experimental non-smallcell lung cancer," The Journal of Clinical Investigation, vol. 124, no. 1, pp. 117-128, 2014.

[60] T. I. Peng and M. J. Jou, "Mitochondrial swelling and generation of reactive oxygen species induced by photoirradiation are heterogeneously distributed," Annals of the New York Academy of Sciences, vol. 1011, no. 1, pp. 112-122, 2004.

[61] C. Weydert, B. Roling, J. Liu et al., "Suppression of the malignant phenotype in human pancreatic cancer cells by the overexpression of manganese superoxide dismutase," Molecular Cancer Therapeutics, vol. 2, no. 4, pp. 361-369, 2003.

[62] K. Hayano, F. Tian, A. R. Kambadakone et al., "Texture analysis of non-contrast-enhanced computed tomography for assessing angiogenesis and survival of soft tissue sarcoma," Journal of Computer Assisted Tomography, vol. 39, no. 4, pp. 607-612, 2015.

[63] K. C. Pramanik, S. R. Boreddy, and S. K. Srivastava, "Role of mitochondrial electron transport chain complexes in capsaicin mediated oxidative stress leading to apoptosis in pancreatic cancer cells," PLoS One, vol. 6, no. 5, article e20151, 2011.
[64] C. Glorieux, N. Dejeans, B. Sid, R. Beck, P. B. Calderon, and J. Verrax, "Catalase overexpression in mammary cancer cells leads to a less aggressive phenotype and an altered response to chemotherapy," Biochemical Pharmacology, vol. 82, no. 10, pp. 1384-1390, 2011.

[65] M. Ott, V. Gogvadze, S. Orrenius, and B. Zhivotovsky, "Mitochondria, oxidative stress and cell death," Apoptosis, vol. 12, no. 5, pp. 913-922, 2007.

[66] W. S. Yang, R. SriRamaratnam, M. E. Welsch et al., "Regulation of ferroptotic cancer cell death by GPX4," Cell, vol. 156, no. 1-2, pp. 317-331, 2014.

[67] M. J. Hangauer, V. S. Viswanathan, M. J. Ryan et al., “Drugtolerant persister cancer cells are vulnerable to GPX4 inhibition," Nature, vol. 551, no. 7679, pp. 247-250, 2017.

[68] J. S. Teodoro, A. M. Simões, F. V. Duarte et al., "Assessment of the toxicity of silver nanoparticles in vitro: a mitochondrial perspective," Toxicology In Vitro, vol. 25, no. 3, pp. 664-670, 2011.

[69] N. Dashzeveg and K. Yoshida, "Cell death decision by p53 via control of the mitochondrial membrane," Cancer Letters, vol. 367, no. 2, pp. 108-112, 2015.

[70] G. Kroemer, L. Galluzzi, and C. Brenner, "Mitochondrial membrane Permeabilization in cell death," Physiological Reviews, vol. 87, no. 1, pp. 99-163, 2007.

[71] K.-Y. Kim, S. N. Yu, S. Y. Lee et al., "Salinomycin-induced apoptosis of human prostate cancer cells due to accumulated reactive oxygen species and mitochondrial membrane depolarization," Biochemical and Biophysical Research Communications, vol. 413, no. 1, pp. 80-86, 2011.

[72] J. I. Jung, S. S. Lim, H. J. Choi et al., "Isoliquiritigenin induces apoptosis by depolarizing mitochondrial membranes in prostate cancer cells B," The Journal of Nutritional Biochemistry, vol. 17, no. 10, pp. 689-696, 2006.

[73] C. Carlson, S. M. Hussain, A. M. Schrand et al., "Unique cellular interaction of silver nanoparticles: size-dependent generation of reactive oxygen species," The Journal of Physical Chemistry B, vol. 112, no. 43, pp. 13608-13619, 2008.

[74] S. S. Lin, H. P. Huang, J. S. Yang et al., "DNA damage and endoplasmic reticulum stress mediated curcumin-induced cell cycle arrest and apoptosis in human lung carcinoma A-549 cells through the activation caspases cascade- and mitochondrial-dependent pathway," Cancer Letters, vol. 272, no. 1, pp. 77-90, 2008.

[75] B. Zhu, Y. Li, Z. Lin et al., "Silver nanoparticles induce HePG-2 cells apoptosis through ROS-mediated signaling pathways," Nanoscale Research Letters, vol. 11, no. 1, p. 198, 2016.

[76] Y. Zhang, H. Lu, D. Yu, and D. Zhao, "AgNPs and Ag/C225 exert anticancerous effects via cell cycle regulation and cytotoxicity enhancement," Journal of Nanomaterials, vol. 2017, Article ID 7920368, 10 pages, 2017.

[77] W. Zhou, P. J. Simpson, J. McFadden et al., "Fatty acid synthase inhibition triggers apoptosis during $\mathrm{S}$ phase in human cancer cells," Cancer Research, vol. 63, no. 21, pp. 73307337, 2003.

[78] F. Salehi, H. Behboudi, G. Kavoosi, and S. K. Ardestani, "Chitosan promotes ROS-mediated apoptosis and S phase cell cycle arrest in triple-negative breast cancer cells: evidence for intercalative interaction with genomic DNA," RSC Advances, vol. 7, no. 68, pp. 43141-43150, 2017.

[79] H. Hu, N. S. Ahn, X. Yang, Y. S. Lee, and K. S. Kang, "Ganoderma lucidum extract induces cell cycle arrest and apoptosis 
in MCF-7 human breast cancer cell," International Journal of Cancer, vol. 102, no. 3, pp. 250-253, 2002.

[80] E. Panzarini, S. Mariano, C. Vergallo et al., "Glucose capped silver nanoparticles induce cell cycle arrest in HeLa cells," Toxicology In Vitro, vol. 41, pp. 64-74, 2017.

[81] X. Li, L. Xu, A. Shao, G. Wu, and N. Hanagata, "Cytotoxic and genotoxic effects of silver nanoparticles on primary Syrian hamster embryo (SHE) cells," Journal of Nanoscience and Nanotechnology, vol. 13, no. 1, pp. 161-170, 2013.

[82] T. I. Peng, M. S. Lin, and M. J. Jou, "Dual phases of respiration chain defect-augmented mROS-mediated $\mathrm{mCa}^{2+}$ stress during oxidative insult in normal and $\rho^{0} \mathrm{RBA} 1$ astrocytes," Oxidative Medicine and Cellular Longevity, vol. 2013, Article ID 159567, 9 pages, 2013.

[83] D. M. Yancey, J. L. Guichard, M. I. Ahmed et al., "Cardiomyocyte mitochondrial oxidative stress and cytoskeletal breakdown in the heart with a primary volume overload," American Journal of Physiology-Heart and Circulatory Physiology, vol. 308, no. 6, pp. H651-H663, 2015.

[84] P. Chairuangkitti, S. Lawanprasert, S. Roytrakul et al., "Silver nanoparticles induce toxicity in A549 cells via ROSdependent and ROS-independent pathways," Toxicology In Vitro, vol. 27, no. 1, pp. 330-338, 2013.

[85] P. Watcharasit, S. Suntararuks, D. Visitnonthachai, A. Thiantanawat, and J. Satayavivad, "Acrylonitrile induced apoptosis via oxidative stress in neuroblastoma SH-SY5Y cell," Journal of Applied Toxicology, vol. 30, no. 7, pp. 649-655, 2010. 


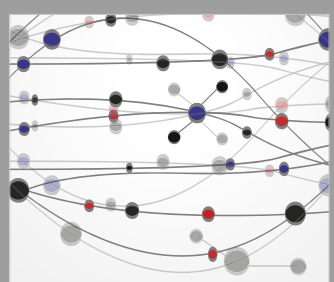

The Scientific World Journal
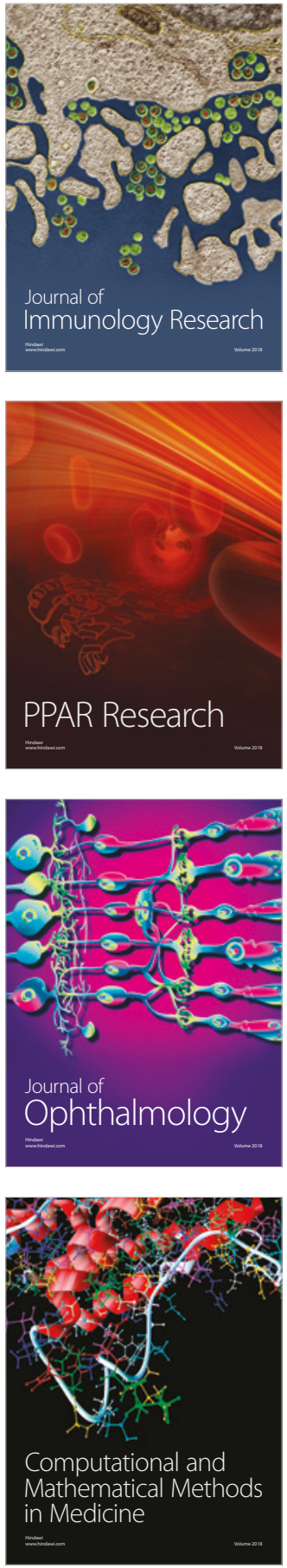

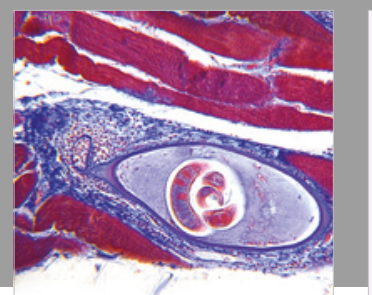

Gastroenterology Research and Practice

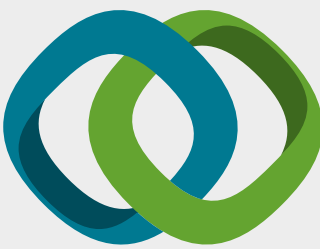

\section{Hindawi}

Submit your manuscripts at

www.hindawi.com
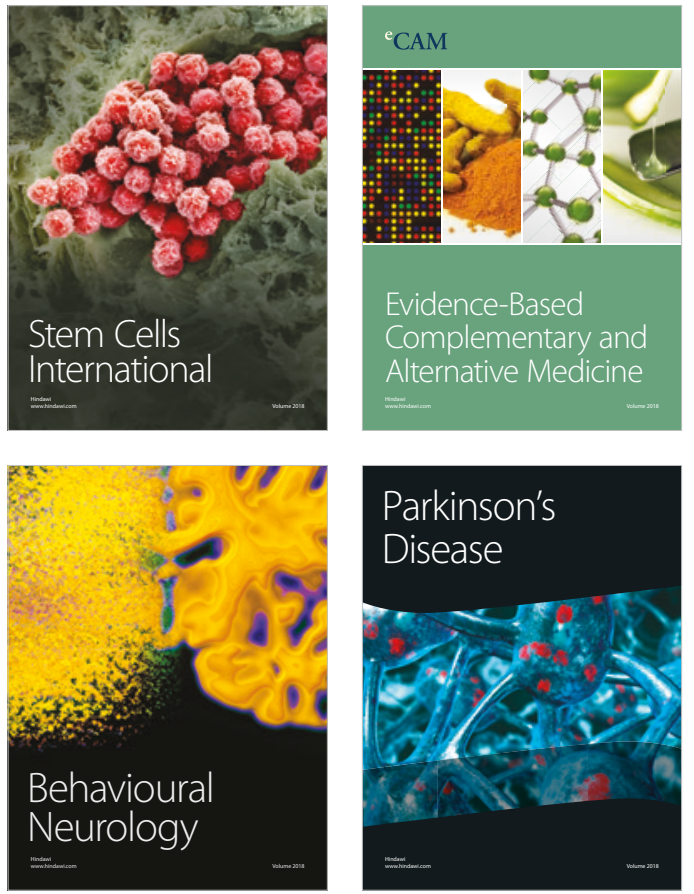

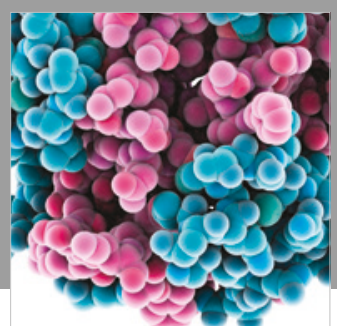

ournal of

Diabetes Research

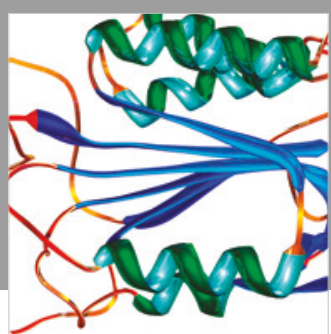

Disease Markers
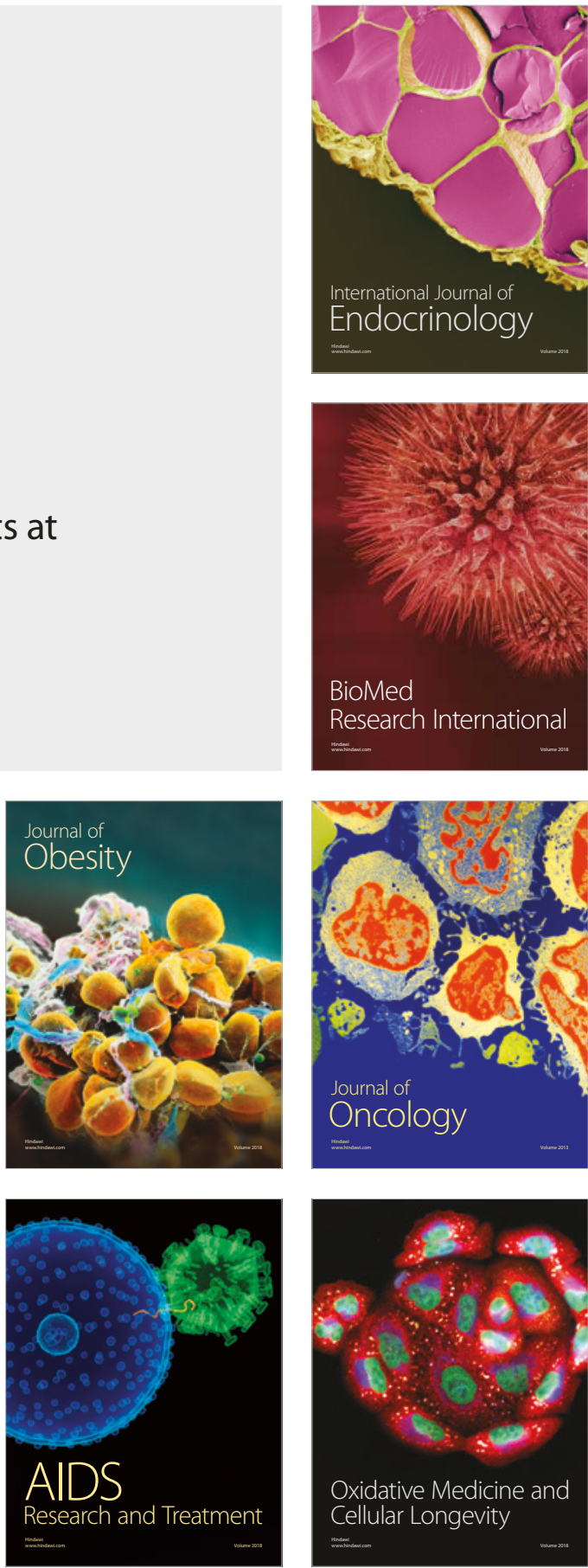